\title{
1. Cumulative creativity, collaboration and borrowing
}

Where the mechanics of creativity in ancient, mediaeval and Renaissance eras are discussed, together with the role of borrowing, imitation and copying in the development of popular culture. Our shift to a different paradigm that perceives borrowing and copying as a nuisance rather than an engine of creativity will be taken up in due course, in a later chapter. Here is introduced the idea of cumulative and collective creativity as opposed to solitary authorship. Authors and public in the past internalized well the perception that creativity is a cumulative act. Modern copyright law has finally sidelined that perception. This argument, developed over the course of the book, is my core critique of the present copyright system based on the exclusivity principle, which structurally neglects the cumulative nature of creativity. The next chapters highlight that we produced the largest portion of our immortal culture under a fully open regime as far as access to pre-existing expressions and reuse is concerned. Conversely, the endowment of strong property rights on creativity may actually have impoverished our capacity to produce long-lasting culture.

Come 40,000 years ago an Aurignacian man became an author. As he was unaware of authorship rights, sheer beauty and reputation were driving his laborious carving of a woolly mammoth tusk into the Venus of Hohle Fels, the first undisputed example of art. ${ }^{3}$ Sculpture and figurative art were born, and painting came shortly thereafter. ${ }^{4}$ Most likely, the oldest cave paintings yet discovered were made 35,000 years ago in the Chauvet Cave, close by the French village of Vallon-Pont-d'Arc. ${ }^{5}$ The art in the caves spread rapidly throughout Europe and Asia. In Lascaux, south-western France, the memory of a perfected prehistoric art is on

3 Nicholas J Conard, 'A Female Figurine from the Basal Aurignacian of Hohle Fels Cave in Southwestern Germany' (14 May 2009) 459 Nature 248.

4 See generally Jean Clottes, Cave Art (Phaidon Press 2008); Gregory Curtis, The Cave Painters: Probing the Mysteries of the World's First Artists (Knopf 2006).

5 See generally Jean-Marie Chauvet, Eliette Brunel Deschamps and Christian Hillaire, Chauvet Cave: the Discovery of the World's Oldest Paintings (Thames \& Hudson 2001) (1996); Jean Clottes, Chauvet Cave: The Art of Earliest Times (U Utah Press 2003). 
display across the vaults and halls of a complex of caves. ${ }^{6}$ The perfection of this artistry is puzzling. Some of the paintings show techniques that were long supposed to have been invented later in time. The mastery of perspective and motion on display at Lascaux and other sites was lost in Western art until Paolo Uccello in the fifteenth century. ${ }^{7}$

The power and beauty of prehistoric art is also rooted in the environmental conditions under which it was created. The art adorning the caves of Lascaux is commonly referred to as Ice Age art. Although Aurignacians and Magdalenians were struggling for survival in the Glacial Age, human creations were detached from functional preoccupations. Speaking of Lascaux, Henri Breuil emphasized the intensity and inspiration of Ice Age art by noting that 'the variety and number of successive techniques, following each other in a relatively brief time, is indicative of a sort of artistic fever, rich in inspiration and experiment' ${ }^{8}$ If nonfunctional creativity occurred under those circumstances, it is obvious to argue that the human impulse to create is relentless. Most likely, that impulse should grow steadily with social, cultural and technological advancement. $^{9}$

What may have moved the Aurignacian or the Magdalenian man to create is open to conjecture. Aurignacians coexisted for a long time with the Neanderthals; however, excavations of Neanderthal sites have not shown the presence of artistic artefacts. ${ }^{10}$ Some argued that cave paintings and primitive portable art represented the manifestation of a human nature that distinguished our ancestors from other animals. ${ }^{11}$ By conceiving themselves as different from animals, humans became authors. The word 'author' perhaps translates the emergence of this process of self-consciousness. In one possible etymological origin, 'author', in fact,

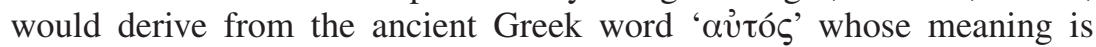
'self'. Authorship would be the means to express our human self.

6 See Norbert Aujoulat, Lascaux: Movement, Space, and Time (H N Abrams 2005); Mario Ruspoli, The Cave of Lascaux: the Final Photographs (H N Abrams 1987).

7 See Curtis (n 4) 110.

8 Henri Breuil, Four Hundred Centuries of Cave Art (Hacker Art Books 1979) (1952) 151.

9 Cf James Boyle, 'The Second Enclosure Movement and the Construction of the Public Domain' (2003) 66 Law \& Contemp Probs 33, 45-46 (referring to the 'innate human love of creation that continually drives us to create new things even when homo economicus would be at home in bed, mumbling about public goods problems').

10 See Clottes (n 4) 12; Curtis (n 4) 35-36.

11 See Max Raphael, Prehistoric Cave Paintings (Pantheon 1945) 2. 
Humanity, authorship and creativity would, therefore, be indissolubly related concepts. Metaphorically, the emergence of authorship would relate to the eating of the apple of forbidden knowledge. This symbolism - which is the demiurgic device of Western culture - would describe the painful detachment from our primordial, purely zoological existence. Bear in mind that I will return again to alternative etymologies of the word 'author' because they contain, I think, some hidden truths.

If identity self-consciousness can be singled out as one metaphysical explanation of the emergence of authorship, there are more practical reasons to be attached to the spur of creativity in the Upper Paleolithic and in human society generally. Historical memory, social participation, reputation, education, mysticism and religion may be some among the alternative primitive motivational drivers.

Supernatural, religious and propitiatory rites have largely been connected to the primordial art and painting in the caverns. Hunting-magic theories were initially formulated, only to later lose part of their appeal. ${ }^{12}$ For these theories, paintings in the caves would have been created as part of a propitiatory rite preceding hunting expeditions. Alternatively, the cave paintings may have been the result of the creative activity of shamans trying to reproduce their own visions induced by drugs or other means. ${ }^{13}$ In any event, mysticism, authorship and creativity were certainly interrelated matters at the origins. Figures likely to be identified as deities or mystical characters were repeatedly discovered in the caves, such as in the cave of Les Trois-Frères. ${ }^{14}$ However, religious concerns are only a partial explanation of the reasons that compelled humans to create. Modern statistical studies of the evolution of Paleolithic art have confirmed - to the extent that any certainty is possible at all in this field of studies - that decorated sanctuaries may have existed distinct from other caves. ${ }^{15}$ Again, within the same caves, different types of chambers, easily accessible or inaccessible recesses, may have played different roles. Hypotheses based on footprints found in the caves, which seem to belong in large quantities to young men, would seem to reconnect the sanctuary with some initiation ceremony. ${ }^{16}$

12 See Breuil (n 8) 23. See also Arnold Hauser, The Social History of Art (Routledge 1999) (1951) 3-8.

13 See Jean Clottes and David Lewis-Williams, The Shamans of Prehistory:

Trance and Magic in the Painted Caves (Abrams 1999).

14 See Curtis (n 4) 165-186.

15 See Ruspoli (n 6) 80-82.

16 ibid 82-84. 
Max Raphael, suicidal genius and philosopher of art, proposed a provocative theory of cave art. The following research has largely plagiarized Raphael's insights. In Raphael's intuition, cave art would become a highly cumulative and collaborative form of creativity. Raphael argued that the individual paintings were part of a planned composition that supposedly superimposed and added images throughout the ages to transmit the history of social relations. Raphael noted that the same animals are painted over and over in all the caves with a consistent characterization for each species. Additionally, Raphael showed that the animals in the caves were grouped around lines and patterns. Each animal species would represent a different clan. The disposition and superimposition of the animals would represent clans' interactions:

[a]nimals pictured one inside the other may represent pregnancy; this device may also be interpreted to mean alliance in the struggle, while the superimposition of animals may stand for domination, mediation or promise of support. ... At Font-de-Gaume a male and a female bison are first shown in a combat and then as a united group ..., which can be interpreted either as a wedding or a ceremony of reconciliation between two clans; and inversely, on the last wall at Les Colombettes, the dissolution of such a united group is depicted in a painting showing two representatives of the Lybian breed of horses taking away a male in a group of horses belonging to the Tarpan breed, attended and aided by friends (mammoths) and enemies of the combined horse clans. ${ }^{17}$

If Max Raphael's intuition is right, the symbolism of the cave paintings would be a primitive form of alphabet and written language. The paintings would represent a chronicle of historical happenings. This way, it is fascinating to imagine that creativity was born as an integrated multimedia device. The same conclusions reached by Raphael were reinforced by the more scientific approach of the studies of Annette Laming-Emperaire. Discussing the meaning of the themes developed by prehistoric rock art, Laming-Emperaire noted that:

[t]hey could be mythic and recount for example the origin and history of certain human group in its rapport with the animal species; they could solidify a very ancient metaphysics and express a system of existence where each species, animal or human, has its role, and where the sexual division among beings plays a primordial role; they could be religious and bring supernatural beings onto the scene. They could be all of that at the same time - mythical, metaphysical, and religious - without the distinction that we introduce among these different modes of thinking having great significance, and all applied at

\footnotetext{
17 Raphael (n 11) 6.
} 
the dawn of human thought. ... It [Laming-Emperaire's study] allows us, however, to pass from the notion of a magical Paleolithic art to that of an art that is far more complex and rich, pregnant with a new significance. We see in the lines of this art an unexpected world, a mythical world that was already rich in traditions, which were undoubtedly preceded by other, earlier traditions, now lost forever. For the first time in the history of humanity, the artists of quaternary caves fixed on rocks their representations of humans and Earth, their quest to integrate themselves into the great animal adventure that played out around their encampments. It is well worth the effort to try to decipher this first Treatise of Nature. ${ }^{18}$

At least in some instances, the initiation ceremonies may in fact have been learning experiences. Caves could have been the equivalent of educational institutions. Cave walls could have served as a gigantic dashboard. By way of guessing, the entire cave structure could have served as a repository of past stories and information. The experience in the cave may have resembled that of an interactive visit to a museum by young pupils, guided through the vaults by the artists that may have served as educators more than shamans.

Education and transmission of knowledge may have been a pivotal factor in the emergence of creativity. The immutable similarity of the artistic techniques of cave paintings seems to suggest that the skills of painting were taught. ${ }^{19}$ Very likely, painting skills were thought to transmit knowledge and beliefs in a first form of formal canon. The quality of prehistoric paintings suggests that these works were done by professionals. The Paleolithic cave painter, 'therefore, seems to have been the first representative of specialization and the division of labour', who emerged, "as the first "professional" and is, as the possessor of special gifts, the harbinger of the real priestly class, which will later lay claim not only to exceptional abilities and knowledge but also to a kind of charisma and will abstain from all ordinary work'. ${ }^{20}$ The artists may have spent a considerable part of their life learning, practising and teaching. Corrected pupils' drawings were found on the walls of the caves, together with sketches and rough drafts. It is highly probable that this is some

18 See Annette Laming-Emperaire, La Signification de l'Art Rupestre Paléolithique (Picard 1962) as cited in Curtis (n 4) 145. See also Amir D Aczel, The Cave and the Cathedral: How a Real-Life Indiana Jones and a Renegade Scholar Decoded the Ancient Art of Man (Wiley and Sons 2009) 105.

19 See Curtis (n 4) 18-19.

20 See Hauser (n 12) 18. 
evidence of an organized educational activity. Schools, masters and local trends may have been at work as well. ${ }^{21}$

The same educational model could have been applied to other forms of prehistoric creativity, such as music, that are now gone forever because there was no writing. Definite rhythm, repetitions and stock phrases of later oral literature and stage art were probably inherited from music, dancing, songs and chanting originally passed through the generations as a form of educational device. Learning, creativity and authorship, hence, would also be strongly intertwined concepts.

Cave art in Lascaux and other sites is the first form of peer production and mass collaboration. Throughout the ages, prehistoric artists from the Magdalenian people have performed a complex depiction of life in the caves of Lascaux, as a continued discourse, symbolic and sublime, between man, nature and God. Thousands of animals, human figures and abstract signs were progressively painted and engraved to create the Sistine ceiling of the caveman. ${ }^{22}$ Lascaux may then enlighten us about the original participative and collaborative nature of creativity. Common interest embraces - and enhances - individual authorship all along the curves, bumps and flat surfaces of the caverns' ceilings, walls and vaults. Henri Breuil discerned the collaborative character of cave art with striking acumen:

[t]his is no longer the work of an individual, but a collective, social affair, showing a true spiritual unity, I am inclined to say, an orthodoxy, suggesting some sort of institutions registering the development of this Art by the selection and instruction of those mostly highly gifted. ... It was not individual fancy which produced the painted caves, but some such institutions which directed, and, in each period, created uniformity of expression. If at the start, some gifted individuals were needed to lay the foundations of artistic expression, its development shows a control and exceptional common interest. ${ }^{23}$

Breuil's considerations might help in drawing an early parallel with modernity, and perhaps postmodernity. It is embedded in the essential nature of human creativity to be communal and collaborative. Apparently, this notion has been largely forgotten by modern policies. Actually, the generative capacity of this notion has been rediscovered by the networked digital creative process based on remixing and mash-up. At this point,

21 See Breuil (n 8) 23; Hauser (n 12) 17-18.

22 See Fernand Windels, The Lascaux Cave Paintings (Viking 1950) (1948) originally published as Lascaux: Chapelle Sixtine de la Préhistorie (1948).

23 Breuil (n 8) 22-23. 
politics for creativity appear to lag behind. My work aims thus at re-emphasizing the cumulative and collaborative nature of creativity and promoting its prominence in the policy discourse.

This book claims that our current conception of authorship as coextensive with individual originality may not have been the dominant discourse until the pre-Romantics. While for most of recorded history there has been at least some interest among authors and patrons in some form of exclusive connection with the work they created or facilitated (in the form of attribution, if not copy prevention), that interest has coexisted with cumulative creativity. ${ }^{24}$ Undeniably, the history is full of examples in which plagiarism or unoriginality were portrayed as moral ills, examples in which work done collectively was seen as inferior to work done by individual geniuses, and examples of patron-owners trying to stop copying of works they had commissioned. However, there is a well-marked historical path suggesting that creativity has been a predominantly cumulative, collective and communitarian effort. ${ }^{25}$ Cumulative creation has historically been - and continues to be - the dominant form of creativity in many cultural settings.

For most human cultural history, openness dominated artistic and literary craftsmanship and promoted derivative creativity. The largest part of our culture has been produced under a paradigm where imitation, even plagiarism, social and collaborative authorship were constitutive elements of the creative moment. A meaningful explanation of the affluence of past popular culture may be found in dynamics of sharing and transmitting culture that developed from Homer to Shakespeare. Pre-copyright

24 This tension intertwines with another struggle characterizing the history of creativity: the tension between the market and gift economy. I will discuss the historical development of the market and gift economy in creativity later in Chapter 3.

25 I would like my readers to be aware that I do not intend to undermine the existence of an inner impulse to create that may exist detached from any communitarian participation and may develop in complete solitude. That individual urge to create will always be an undeniable primary creative impulse. Individual originality will be ineludibly present: '[w]hen we analyse human activity, after removing all determining causes there remains behind in it something original which, instead of being overpowered by their influence, is more likely to transform them', Wilhelm von Humboldt as cited in Haijo Westra, 'Individuality, Originality and the Literary Criticism of Medieval Latin Texts' in John Marenbon (ed), Poetry and Philosophy in the Middle Ages: A Festschrift for Peter Dronke (Brill 2001) 281. However, the final creative artefact is the result of much more complex creative dynamics. Individual contributions inextricably intertwine with cumulative and communitarian participation. 
creativity spread from a continuous line of reuse and juxtaposition of pre-existing expressive content, transitioning from orality to textuality and then mashing up the two traditions. Emulation, imitation, plagiarism, borrowing, remixing and recombination had a constant and recurring demiurgic power in the history of creativity. In particular, popular literary culture flourished powerfully in the open pre-copyright system through creation, sharing, development and promotion of iconic figures and characters. Authorship was a community effort that entailed an inclusive relationship with the surrounding community. In the 1st Paradigm, miscellaneous forms of creativity coexisted in a state of undifferentiated harmony, as vision, inspiration and originality could only be achieved through erudition, tradition and borrowing.

In addition, there has always been significant philosophical and practical opposition to the premise that ideas and expressions can be owned once expressed. For the large majority of human cultural history, economic incentive occupied a secondary role in motivating authors to create. Creativity was mainly a matter of participation. Nonetheless, under a regime of limited economic incentive for creation and confined commodification of information, humanity produced the greatest portion of its culture and knowledge. To mention some, the Bible, the Qur'an, the Indian Mahābhārata and Rāmāyana, the Greek Iliad and Odyssey, the Roman Aeneid, the Scandinavian sagas, the German Lay of the Nibelungs, the Celtic legends of Arthur, the romances and the chanson de geste all came to life well before strong economic rights were attached to creativity. Later, Petrarch declaimed the Dolce Stil Novo with his poems, Dante wrote the Divina Commedia, Chaucer fathered English literature, Ludovico Ariosto sent Astolpho riding the hippogriff to the moon to recover Orlando's brain in the Orlando Furioso, Cervantes unleashed his Don Quixote de la Mancha against windmills and earlier epic literature, and Shakespeare gave immortal life to the love of Romeo and Juliet. This list might lead one to wonder whether the endowment of strong property rights on creativity impoverished our capacity to produce long-lasting culture, especially popular culture.

These points tend to undermine the currently popular discourse that exclusive ownership inevitably or necessarily leads to the creation of more or better works of authorship. Today, modern copyright policies turn derivative creativity into an apparent nuisance to be paid off under a strict permission standard. My work argues that cumulative and sedimentary creativity is profoundly capable of generating excellent works but frustrated by strong legal encumbrance. The systematic historical framework that I develop in this book is very useful in demonstrating the intuitively obvious but difficult-to-prove idea that progress depends upon 
building on what came before. Based on an examination of these historical trends, it is reasonable to conclude that the legal encumbrance is probably doing more harm than good for overall creation.

\section{PLATONIC MIMẼSIS AND PLAGIARISM}

Plato - and later Aristotle - made imitation the general principle of art. ${ }^{26}$ Art was mimēsis of reality, Plato said. In Plato and Aristotle's view, poetry, music, dance - and art generally - imitated reality. In his Poetics, Aristotle added that imitation is the distinctive character of humanity: 'indeed we differ from other animals in being most given to mimēsis and in making our first steps in learning through it - and pleasure in instances of mimesis is equally general' ${ }^{27}$ The Platonic concept of artistic imitation deeply influenced Hellenistic and Roman aesthetics. The emphasis on imitation naturally made copying and borrowing constitutive instruments of creativity. This theory dominated most of our history of aesthetics and was discredited only under the influence of Romanticism, where the idea of Platonic imitation was regarded as nothing more than 'a systematic violation of art', 'depriving it of all its charms'.28

In premodern history, coexistence of cumulative, collaborative and more individualistic creative approaches was commonplace. Appropriation and collaboration have always been widespread parts of the creative process, although they have not always been accepted as proper or preferred to individual or 'original' creation. The catalogue of parallelisms, similarities and absorption of expressions of another is endless in ancient Greek literature. The tragedians abundantly pillaged each other. Philostrates of

26 See eg Plato, 'Cratylus' [423cd] in XII Plato in Twelve Volumes (Harold Fowler trans, Harvard UP 1921); Plato, 'Republic' [393c, 399a-c, 401a] in V-VI Plato in Twelve Volumes (Paul Shorey trans, Harvard UP 1969); Plato, 'Laws' [655d, 668a-c, 795e] in X-XI Plato in Twelve Volumes (RG Bury trans, Harvard UP 1967-1968); Aristotle, 'Poetics' [1448b] in XXIII Aristotle in 23 Volumes (W H Fyfe trans, Harvard UP 1932); Aristotle, 'Rhetoric' [1371-1371b, 1376a, 1398b] in XXII Aristotle in 23 Volumes (J H Freese trans, Harvard UP 1932). See also eg Willem Verdenius, Mimesis: Plato's Doctrine of Artistic Imitation and Its Meaning to Us (Brill Archive 1972).

27 See Aristotle, Poetics (n 26) 1448 b.

28 Otto Apelt, Platonische Aufsätze (Leipzig-Berlin 1912) 68-79 as cited in Verdenius (n 26) 1-2. 
Alexandria accused Sophocles of having pillaged Aeschylus, ${ }^{29}$ Aeschylus of having permitted himself to draw too much inspiration from Phrynichus, and Phrynichus of having taken his material from the writers who preceded him. ${ }^{30}$ Aristophanes then accused Aeschylus of having largely carried on literary free riding. The comedian puts into the mouth of Aeschylus, whom he makes one of the characters in The Frogs, the following words, addressed to Euripides:

[w] hen I first read over the tragedy which you placed in my hands, I found it difficult and bombastic; I at once made a severe condensation, freeing the play from the weight of rubbish with which you had overloaded it; I then enlivened it with bright sayings, with pointed philosophic subtleties and with an abundance of brilliant witticisms drawn from a crowd of other books; and finally I added some pithy monologues, which are in the main the work of Ctesiphon. ${ }^{31}$

Plato confirmed the point on Euripides by noting that the choruses of Euripides' tragedies reproduced faithfully the teachings of the philosopher Anaxagoras. ${ }^{32}$ Aristophanes was himself not beyond criticism. He was charged with having made free use of the comedies of Cratinus and Eupolis, who in turn were accused of plagiarizing Aristophanes. ${ }^{33}$ Menander is reported to have transcribed an entire drama, The Augur of Antiphanes, into The Superstitious Man, and Latinus published a sixbook work under the title Of Menander's Appropriations. ${ }^{34}$ Ancient Greek philosophers and historians borrowed and imitated from contemporary and previous work as much as the theatrical dramatists. Even Plato occasionally yielded to the temptation of borrowing from others. Some lines by Aulus Gellius report charges against Plato of having plagiarized a treatise of the Pythagorean philosopher Philolaus:

29 See Eusebious Pamphili, Evangelicae Preparationis [Preparation for the Gospel] 465d (Edwin Hamilton Gifford ed, Typographeo Academico 1903) (circa 313-339 A.D.).

30 See George H Putnam, Authors and Their Public in Ancient Times: A Sketch of Literary Conditions and of the Relations with the Public of Literary Producers, from the Earliest Times to the Fall of the Roman Empire (G P Putnam's sons 1893) 69-70.

31 Aristophanes, The Frogs [ln 939-944] as cited in Putnam (n 30) 71.

32 See Alexander Lindey, Plagiarism and Originality (Harper 1952) 65.

33 See eg Zachary Biles, Aristophanes and the Poetics of Competition (CUP 2011) 147.

34 See Eusebious (n 29) 465d. 
The bitter satirist Timon wrote a highly abusive work, which he entitled $\sigma i \lambda \lambda$ os. In that book he addresses the philosopher Plato in opprobrious terms, alleging that he had bought a treatise on the Pythagorean philosophy at an extravagant figure, and that from it he had compiled that celebrated dialogue the Timaeus. Here are Timon's lines on the subject:

Thou, Plato, since for learning thou didst yearn,

A tiny book for a vast sum did'st buy,

Which taught thee a Timacus to compose. ${ }^{35}$

The historian Theompopus made use, without credit, of long passages from Isocrates, Andros and Xenophon. ${ }^{36}$ Alcaeus wrote a parody of the historian Ephorus' literary thefts and Lysimachus wrote a book entitled The Robberies of Ephorus. ${ }^{37}$ Herodotus' uncredited reuse of others' material was well known, as discussed in a letter from Pollio to Soteridas and reported by Eusebious of Caesarea. ${ }^{38}$ Further, the great difference of style and forms of expression in Plutarch's Lives creates the suspicion that many portions are taken bodily, and without credit, from other authors. ${ }^{39}$ Likewise, the orators borrowed heavily from each other. ${ }^{40}$ Again, Philostrates remarked that Isocrates Panegyricus 'gave rise to the charge that it had been compiled from the works of Gorgias on the same subject'. ${ }^{41}$ Aeschines makes free use in his discourses of those of Lycias and Andocides. ${ }^{42}$ Even Demosthenes' Aphobos and Pantcenetos reproduced identical passages from the Discourses on Ciron by the old instructor of Demosthenes, Isseus. ${ }^{43}$ But Demosthenes is himself plagiarized, as noted by a fragment of Porphyry who 'inform[ed] against the charming Hyperides as having stolen many things from Demosthenes, both in the speech Against Diondas and in the one Concerning the bribes of Eubulus'.44

35 Aulus Gellius, Noctes Atticae III17, in The Attic Nights of Aulus Gellius (John Rolfe trans, Harvard UP 1927) (circa 159 A.D.) 299.

36 See Eusebious (n 29) 464 c-d, 465 a-c.

37 ibid $467 d$.

38 ibid.

39 See Putnam (n 30) 72-73.

40 See Titus Flavius Clement, The Writings of Clement of Alexandria (William Wilson trans, T\&T Clark 1869) 315, 304-319.

41 Lucius Flavius Philostratus, Lives of the Sophists (Wilmer Wright trans, W Heinemann 1922) (circa 231-237 A.D.) 55-56.

42 See eg John Dobson, The Greek Orators (Methuen and Co 1919) 34.

$43 \quad$ See Putnam (n 30) 69.

44 Eusebious (n 29) 465d. 
If the Greeks 'accused' each other of appropriation, this does not mean that that appropriation was presumptively disfavoured, although attribution might have been appreciated. My historical research supports the claim that attribution has generally always been more important to authors than originality or exclusivity. Community participation ontologically characterized the Greek creative process. As seen, the practice of reusing or even bodily plagiarizing other works - so generalized as accusations show ${ }^{45}$ - had deep roots in ancient Greek philosophy. Plato's doctrine of artistic imitation powerfully justified the imitative and cumulative nature of ancient Greek creativity. Furthermore, the orality of Greek creativity may have played a determining role in the perception of intellectual appropriation. ${ }^{46}$ All through ancient Greek literary history, creative works were mainly sung, recited, declaimed or read in public session. The practice was due mainly to the scarcity of books and the inherently oral nature of the ancient Greek cultural tradition. Repeated public performances and scarcity of written texts may perhaps have enhanced memorization of various genres of creative works. Primarily poetry, especially epic poetry, but also dramatic, philosophical and historical materials were perhaps memorized by many in discrete portions, so as to become more of an inner possession of the hearer's mind than would be possible for a modern reader of books. In this respect, as Putnam poetically put it, the ancient Greek:

inherited from his ancestors the poetry of the preceding generation with the same sense of natural right as that with which he took possession of his ancestral acres; and he absorbed into his memory for his daily enjoyment the poetry of his own day with the same freedom and almost the same unconsciousness as that with which he took into his lungs the air about him. In this way the literature with which he had to do became really a part of himself ... . ${ }^{47}$

Cultural creations were truly 'free as the air to common use'. ${ }^{48}$ Reuse, imitation and appropriation were as natural as breathing for the ancient Greeks. Hence, bodily appropriation of others' creativity was in part unconscious and necessitated by the cultural environment breeding Greek citizens since childhood. Most likely, the public was not very active in

45 Cf ibid 467d (reporting that the sophist Aretades, wrote a volume, unfortunately lost, on the similarity or identity of intellectual creations).

46 See Putnam (n 30) 107-109.

47 ibid 108.

48 International News Serv v Associated Press, 248 US 215, 250 (1918) (Brandeis, J, dissenting). 
discovering the practice, or condemning it. Besides the pretentious skirmishes that may have occurred between authors, condemnation by public opinion was lenient and rare. The borrowings of works of other authors, especially dead authors, seldom became the occasion for any criticism. Public condemnation for uncredited literal appropriation was exceptional and subordinated to several cumulative factors, as perhaps in instances of bodily appropriation of entire works to be entered into public contests by minor writers venturing to appropriate from greater ones. ${ }^{49}$

\section{'ORATIO PUBLICATA, RES LIBERA EST'}

Compared with the Greek tradition, the discussion over the concept of authorship was fairly advanced in the Roman world. However, the Romans too lacked any statutory restraint on falsely claiming authorship of another's work. ${ }^{50}$ Ancient Rome saw to the protection of authors' interests by means of social norms. ${ }^{51}$ A notorious fourth-century A.D. epistolary exchange between Quintus Aurelius Symmachus and Decimus Magnus Ausonius explained the conventional Latin social norms governing authorship. 'Oratio publicata, res libera est', wrote Symmachus in a letter to his fellow poet and friend Ausonius. ${ }^{52}$ Apparently, in previous lost correspondence, Ausonius complained about Symmachus having circulated a work of Ausonius that supposedly had to remain private. ${ }^{53}$ In justifying himself against Ausonius' accusation, Symmachus wrote:

49 Vitruvius reported one of these instances by telling the story of Aristofanes, a librarian of Alexandria, unveiling the appropriation of works of others by a few poets at a public contest organized by the king Ptolemy. See Vitruvius Pollio, De Architectura [Book VII Introduction 4-7] (circa 80-15 B.C.), in Ten Books on Architecture (Morris Morgan trans, Harvard UP 1914) 198. See also Joseph Loewenstein, Ben Jonson and Possessive Authorship (CUP 2002) 70.

50 See Russ VerSteeg, 'The Roman Law Roots of Copyright' (2000) 59 Md L Rev 522, 530; Katharina de la Durantaye, 'The Origins of the Protection of Literary Authorship in Ancient Rome' (2007) 25 B U Int'l L J 37, 58; Salathiel Masterson, 'Copyright: History and Development' (1940) 28 Cal L Rev 620, 623; Harold Streibich, 'The Moral Right of Ownership to Intellectual Property Part I - From the Beginning to the Age of Printing' (1976) 6 Mem St U L Rev 1, 6-7.

51 See Durantaye (n 50) 38.

52 Quintus Aurelius Symmachus, Epistulae 131.

53 See Scott McGill, 'The Right of Authorship in Symmachus' Epistulae 131' (2009) 104 Class Phil 229, 229. 
[b]ut in this I think you are excessively modest, that you complain of me for playing traitor to your book. For it is easier to hold hot coals in one's mouth than to keep the secret of a brilliant work. Once you have let a poem out of your hands, you have renounced all your rights [ius omne potsuisti]: a speech delivered is common property. Or do you fear the venom of some jealous reader, and that your book may smart from the snap of his rude fangs? You are the one man who up to now has owed nothing to partiality, lost nothing through jealousy. Involuntarily everyone, perverse or honest, finds you admirable. Therefore banish henceforth your groundless fears, and let your pen run on so that you may often be betrayed. At any rate assign some didactic or hortatory poem to my name also. Run the risk of my keeping silence; and though I desire to give you proof of it, yet I dare not guarantee it. Well I know how I itch to give voice to your work when you are so popular. For somehow he secures a partnership in the glory who first pronounces another's neat phrases. That is why in comedy authors have won but slight renown, while Roscius, Ambivius, and the other players have had no lack of fame. So spend your leisure in such occupation and relieve my famine with fresh books. But if in your flight from vainglory you dread a chattering informer, do you also guarantee me your silence, that I may safely pretend that what you have written is mine! Farewell. ${ }^{54}$

The incipit and the conclusion of the letter define the coordinates of authorship in ancient Roman society. The letter balances the statement that 'copies of text became common property with the message that the credit for having written a text stood as a private property'. ${ }^{55}$ Symmachus meets Ausonius' complaint by noting that once an author has circulated a work, any capacity of restraining its further circulation is lost. Apparently, Roman authors only enjoyed the right of keeping their work secret. Actually, no Roman legal source ever mentioned a law or a case where an author summoned a judge to complain about the unlicensed or otherwise illegitimate publication of a work. ${ }^{56}$ This principle would shape the perception of the public nature of creativity for the centuries to come and would still play a very influential role at the time of the European 'battles of the booksellers' at the dawn of modern copyright law.

Symmachus employed the word ius to refer to the ability of Ausonius to keep his work secret, that being the sole 'right' to which Ausonius was entitled. The use of the term ius might perhaps suggest the existence of a 'right of non-disclosure' as the only legal position recognized to an

54 Quintus Aurelius Symmachus, Epistulae 131, in II Ausonius (Hugh Evelyn White trans, Putnam 1921) 5 (emphasis added).

55 McGill (n 53) 230.

56 ibid 59. 
author in Roman law. ${ }^{57}$ Only imperial will perhaps could trample on this right and force disclosure of a work against the intention of the author. This is the case for Virgil's Aeneid. ${ }^{58}$ Virgil spent the last 11 years of his life writing the Aeneid. At his death, the work was incomplete. Tucca and Varius, the executors of Virgil's literary estate, were instructed not to publish posthumously any unfinished work. Only the inescapable intervention of the Emperor Augustus forced the disclosure of the manuscript to the public. Suetonius reported the theatrical events surrounding the posthumous publication of the Aeneid as follows:

[Vergil] had arranged with Varius, before leaving Italy, that if anything befell him his friend should burn the 'Aeneid'; but Varius had emphatically declared that he would do no such thing. Therefore in his mortal illness Vergil constantly called for his bookboxes, intending to burn the poem himself; but when no one brought them to him, he made no specific request about the matter, but left his writings jointly to the above mentioned Varius and to Tucca, with the stipulation that they should publish nothing which he himself would not have given to the world. However, Varius published the 'Aeneid' at Augustus' request, making only a few slight corrections, and even leaving the incomplete lines just as they were. ${ }^{59}$

Returning to Symmachus' letter, its conclusive passage seems to shed some additional light on the notion of intellectual appropriation at the time. In particular, the passage seems to confirm the existence of social conventions that discouraged appropriation of the attribution of another's work. Symmachus is acknowledging this social norm by jokingly offering Ausonius to pretend to be the author of his work if Ausonius insists on his modesty and unwillingness to circulate his work. However, Ausonius must guarantee his silence for Symmachus to safely pass off his friend's work as his own. If the public knew that Symmachus had received undeserved acclaim for material written by another, his conduct would correspond to a literary transgression. ${ }^{60}$ It is worth noting, however, that the protection of public faith, instead of a conventional moral right of attribution, might also have triggered Symmachus' concern. Unfortunately, the sources at our disposal are too scarce to come down to a definitive conclusion.

57 See Marilyn Randall, Pragmatic Plagiarism: Authorship, Profit, and Power (U Toronto Press 2001) 61.

58 ibid 66-67.

59 Gaius Suetonius Tranquillus, Vita Vergili 39-41, in II Suetonius (John Rolfe trans, Heinemann 1914) 479.

60 See McGill (n 53) 230-231. 
The emergence of a well-rounded concept of literary credit in Roman society finds its origin also in Martial's emphasis on authorship and plagiarism. His repeated references to literary theft, however, should not be overstated. On one side, they are part of Martial's art of ridicule. On the other, they are very much a personal feature of Martial's character. Martial was the gossip columnist of ancient Rome. ${ }^{61}$ A quest for fame and fortune drove his career in Rome. In fighting his personal battle with reciters appropriating his poetry, Martial coined the term that the moderns have inherited to signify literary theft. Martial describes the literary thief as plagiarius in an epigram addressed to one Quinctianus, whose help Martial was seeking to put a stop to a reciter passing off Martial's epigrams as his own:

[t]o thee, Quinctianus, do I commend my books, if indeed I can call books mine, which thy poet recites. If they complain of a grievous yoke, do thou come forward as their advocate, and defend them efficiently; and when he calls himself their master, say that they were mine, discharged from my hand [manuque missos]. If thou wilt proclaim this three or four times, thou wilt bring shame on the plagiary [impones plagiario pudorem]. ${ }^{62}$

Plagium was a Latin word for kidnapping and the perpetrator of the crime was a plagiarius. ${ }^{63}$ The crime derived its name from the punishment it deserved: to be condemned to the whip - ad plagia. In particular, the term referred to the abduction of children or slaves of others, or, again, the selling of free men into slavery. Therefore, poetic verses become in Martial's metaphor like a slave stolen from his master. Martial's metaphor was indeed extremely successful and remains relevant to the present day.

Martial's concerns were addressed to the bodily appropriation of entire works, then circulated under a new attribution, perhaps with minimal additions or modifications. This was the case for a book by Martial's nemesis, Fidentinus. As reported by another epigram from Martial, the

61 See Garry Wills, Martial's Epigrams (Penguin 2008) 1-2.

62 Marcus Valerius Martialis, I Epigrammata 52 (Rome, circa 86-103 A.D.), in Henry Bohn (ed), The Epigrams of Martial (Bell \& Daldy 1871) 51 (original translation slightly modified). Martial's preoccupation with reciters of his poems, especially one Fidentinus, is bitter and recurring in several epigrams: 'Report says that you, Fidentinus, recite my compositions in public as if they were your own. If you allow them to be called mine, I will send you my verses gratis; if you wish them to be called yours, pray buy them, that they may be mine no longer' ibid I29.

63 See eg Randall (n 57) 60-61. 
only original page of Fidentinus in a book entirely copied from Martial bore on its face the proof of Fidentinus theft:

[o]ne page only in my books belongs to you, Fidentinus, but it bears the sure stamp of its master, and accuses your verses of glaring theft [carmina furto]. Just so does a Gallic frock coming in contact with purple city cloaks stain them with grease and filth; just so do Arretine pots disgrace vases of crystal; so is a black crow, straying perchance on the banks of the Cayster, laughed to scorn amid the swans of Leda: and so, when the sacred grove resounds with the music of the tuneful nightingale, the miscreant magpie disturbs her Attic plaints. My books need no one to accuse or judge you: the page which is yours stands up against you and says, 'You are a thief [Fur es]'. ${ }^{64}$

Indeed, Roman social norms condemned the appropriation without attribution of an entire work. However, the idea of authorship and originality differed substantially from that of the moderns. According to Walter Ong, although 'resentment at plagiarism begins to develop ... [t]he oral commonplace tradition was still strong'. 65

The Roman perception of creativity is far removed from the 'modernist value system, which from the Romantic era onwards has valorised originality and artistic genius and, in consequence, denigrated copying' ${ }^{66}$ Copying, imitation and emulation in ancient creativity was an art in its own right. Honouring and challenging previous models through artistic imitation was a built-in feature, not a bug, of Roman aesthetics. In Elaine Gazda's words, this was the 'ancient art of emulation'. The 'anxiety of influence' of modern authorship was inconceivable to the Romans. ${ }^{67}$ They would have perceived the rejection of the predecessors' influence as 'peculiar, perhaps even foolish' ${ }^{68}$ Seneca the Elder explained the rationale for generalized borrowing and reuse in the Latin creative tradition in the following terms: "not for the sake of stealing, but of open borrowing,

64 Martialis (n 62) I53.

65 See Walter Ong, Orality and Literacy: The Technologizing of the Word (Methuen 1982) 131.

66 Elaine Gazda, 'Beyond Copying: Artistic Originality and Tradition' in Elaine K Gazda (ed), The Ancient Art of Emulation: Studies in Artistic Originality and Tradition from the Present to Classical Antiquity (U Michigan Press 2002) 2.

67 See Harold Bloom, The Anxiety of Influence: A Theory of Poetry (OUP 1973).

68 See Gazda (n 66) 11. 
for the purpose of having it recognized' ${ }^{69}$ A poet might borrow a motif from another poet so as to pay that poet a compliment and have the reader discover that tribute. Henry Nettleship, renowned Virgilian scholar and Oxford professor of the nineteenth century, noted that in early imperial Rome 'no sooner had a fine thought, phrase or even rhythm been struck out by a poet than it became, by common consent, the property of all subsequent writers. To appropriate was not to commit a plagiarism but to do honour to its inventor.' 70 Again, Nettleship pointed out that 'to use a friend's verses seems to have been regarded by the Roman poets as a compliment and a mark of affection.' ${ }^{71}$ This theme would later dominate mediaeval literature. ${ }^{72}$ There is an indissoluble relationship between creativity, borrowing, respect for authority and erudition in ancient and mediaeval times. In this regard, borrowing was a cipher of erudition and a challenge for the reader to disclose the tradition echoing in the modern text.

Leading Roman authors openly spelled out the centrality of past works and models. In particular, originality of theme or story was far less important than it is today. ${ }^{73}$ In contrast, Quintilian regarded imitation as a way to reach excellence:

for there can be no doubt that in art no small portion of our task lies in imitation, since although invention came first and is all-important, it is expedient to imitate whatever has been invented with success. And it is a universal rule of life that we should wish to copy what we approve in others. ${ }^{74}$

69 Seneca the Elder, Suasoriae 37 as cited in Gian Biagio Conte, The Rhetoric of Imitation: Genre and Poetic Memory in Virgil and Other Latin Poets (Cornell UP 1986) 32.

70 Henry Nettleship, Lectures and Essays on Subjects Connected with Latin Literature and Scholarship (Clarendon Press 1885) 123. See also Macrobius, The Saturnalia 511-512 (Percival Davies ed, Columbia UP 1969) (discussing, in appendix B, originality, imitation and plagiarism in ancient Roman and Greek literature).

71 Henry Nettleship, Ancient Lives of Vergil with an Essay on the Poems of Vergil in Connection with His Life and Times (Oxford Clarendon Press 1879) 62.

72 See Jan Ziolkowski, 'The Highest Form of Compliment: Imitatio in the Medieval Latin Culture' in John Marenbon (ed), Poetry and Philosophy in the Middle Ages: A Festschrift for Peter Dronke (Brill 2001).

73 See Durantaye (n 50) 70 (noting that in this respect, Shakespeare's Elizabethan creativity also resembled this character of Roman creativity).

74 Marcus Fabius Quintilianus, IV The Institutio Oratoria (Harold Butler trans, W Heinemann 1922) (circa 35-100 A.D.) § 1021-1022. 
Again, Vitruvius wrote: 'drawing from [the past authors] as it were water from springs, and converting them to our own purposes, we find our powers of writing rendered more fluent and easy, and relying upon such authorities, we venture to produce new systems of instruction'. ${ }^{75}$ In $D e$ oratore, finally, Cicero explained the teaching of imitation to students: '[1]et this then be the first of my precepts, that we show the student whom to imitate, and to imitate in such a way as to strive most carefully after the qualities which are outstanding in the models he imitates'.76 Although Romans appreciated original genius and invention, imitation and copying equally inspired their creative process.

Imitation in Roman literature went hand in hand with the search for excellence. In the Rhetorica ad Herennium, Cicero's Brutus and De Oratore, and Dionysius of Halicarnassus' On Imitation, rhetorical doctrine put forward the conviction that imitation of great authors was the surest instrument for attaining excellence. ${ }^{77}$ Actually, the primary goal in any sphere of Roman life was the pursuit of excellence, rather than originality. ${ }^{78}$ Therefore, Roman creativity, while not denying the importance of originality, regarded it as a quality as long as it led to excellence. Meanwhile, Romans regarded borrowing and imitation highly as necessitated instruments of excellence. Thus, the Roman perspective on originality diverged from the modern. In modern times, originality came to monopolize the creative process. In ancient Rome, originality was only one term of the creativity function, whose desired result was excellence. Lack of originality, therefore, was unlikely to arouse disapproval or even special attention, if excellence was achieved through formal beauty and completeness. Commenting on the the author's role in ancient Rome, a scholar noted:

[f]ollowing the Greek conventions adopted in Rome, the author was not confronted with a completely independent creative task. His role was limited to a maximally faithful - faithful to specific detail and general truth reproduction of the reality surrounding him and the beauty that dwelt within it - the divine order. His task was above all to recognize the beautiful and to imitate it, either through the imitation of nature or through the imitation of the

75 Vitruvius (n 49) Book VII, Introduction, 10.

76 Marcus Tullius Cicero, I \& II De Oratore (Edward Sutton and Harris Rackham trans, Harvard UP 1942) § 2.22.90.

77 See Ziolkowski (n 72) 300.

78 See Ellen Perry, 'Rhetoric, Literary Criticism, and the Roman Aesthetics of Artistic Imitation' in The Ancient Art of Emulation (n 66) 168. 
works of others in which he endeavored to outdo those models in his depiction of this beauty. ${ }^{79}$

The centrality of imitation is also the result of the influence of the Platonic and Aristotelian concept of creativity in Roman society. As mentioned, in Plato and Aristotle, poetry was a mimésis of reality. The Roman conception of creativity extended literary mimessis to the imitation of earlier literature. In the Ars Poetica, Horace crystallized the idea that literary mimessis meant not only imitation of nature, but also imitation of literary precedents and models. ${ }^{80}$ The Romans created an entire body of literature and visual art by referring to, borrowing from and drawing on Greek models. The literary mimēsis initially included exclusively Greek literature, although later was extended to a select group of Roman authors. In the early stage of Roman literature, there were great presumptions that the majority of the dramatic writings that appeared in Rome were in large part based upon Greek originals. ${ }^{81}$ As the assumptions go, Latin poets of the fourth and third centuries were translating the Greeks, or at least paraphrasing them. Ennius - often referred to as the father of Latin literature - was said to have generally simplified and amplified Euripides' plays. ${ }^{82}$ Discussing Ennius' Medea, Cicero stated that it was a 'word for word' translation of the Medea of Euripides. ${ }^{83}$ Again, as mentioned by Cicero, The Young Comrades of Caecilius, or Terence's Maid of Andros were adaptations, or perhaps bodily translations, of two earlier comedies by Menander. ${ }^{84}$

According to modern studies, ancient Roman literature knew three forms of literary imitation: interpretatio, imitatio and aemulatio. ${ }^{85}$ Interpretatio was the less original adaptation and coincided with direct translation of one source. Imitatio was an adaptation that consisted of

79 Durantaye (n 50) 106.

80 Quintus Horatius Flaccus, Ars Poetica ln 119-134 (circa 18 B.C.), in The Works of Horace: Translated Literally into English Prose (Christopher Smart trans, Harper \& Brothers 1863) 306.

81 See Putnam (n 30) 177-178.

82 See George Simcox, I History of Latin Literature from Ennius to Boethius (Longmans, Green \& Co 1883) 34.

83 See Marcus Tullius Cicero, I De Finibus Bonorum et malorum (Harris Rackham (trans), W Heinemann 1914) (circa 45 B.C.) 4.

84 ibid 4-5.

85 See Arno Reiff, 'Interpretatio, imitatio, aemulatio: Begriff und Vorstellung literarischer Abhängigkeit bei den Römern' (PhD Dissertation, Universitat Köln) (Druck Triltsch 1959). See also James Hardin, Translation and Translation Theory in Seventeenth-Century Germany (Rodopi 1992) 59-60. 
borrowing of form, or content, or both from one or more renowned Greek sources. Aemulatio, finally, was a form of creative rivalry. Powerful examples are Virgil's emulation of Homer's epics and Horace's emulation of Alcaeus' lyrics. In analogy with literary imitation, various forms of imitations dominated Roman sculpture as well. ${ }^{86}$ In Roman sculpture, it is possible to distinguish 'true copies', 'free copies' and 'ideal sculpture' as the counterparts of the mentioned interpretatio, imitatio and aemulatio, respectively. ${ }^{87}$

Modern standards of copyright protection may have prevented even the looser form of imitation, the emulation. Since the end of the eighteenth century, the status of imitation has been questionable. In a classic article on imitation in antiquity, Richard McKeon declared ' $[\mathrm{t}]$ he term "imitation" is not prominent in the vocabulary of criticism today. In such use as it still has, it serves to segregate the bad from the good in art.' 88 To the sensibility of the moderns, 'imitation conflicts with ideals (sometimes illusory) of originality, spontaneity, innovation, unconventionality, improvisation, self-expression, and individuality that have held sway since Romanticism' ${ }^{89}$ In contrast, most ancient and mediaeval literary experience is based on imitation of traditional models, according to the principle established by Horace's famous motto 'ausus idem - daring to rewrite' ${ }^{90}$ Macrobius, then, gave scholastic substance to Horace's literary challenge by providing his readers with an articulated description of the literary relationship between auctor and imitator - author and rewriter. Macrobius' Saturnalia illustrated the art of rewriting - or description - in minute detail, as we will discuss in a moment. ${ }^{91}$

86 See eg Elaine Gazda, 'Roman Sculpture and the Ethos of Emulation: Reconsidering Repetition' (1995) 97 Harv Studs Class Phil 121; Rosalind Krauss, 'Retaining the Original? The State of the Question' in Kathleen Preciado (ed), Retaining the Original: Multiple Originals, Copies, and Reproductions (National Gallery of Art 1989) 7-12; Miranda Marvin, 'Copying in Roman Sculpture: The Replica Series' in Retaining the Original 29-45.

87 See Gazda (n 66) 7.

88 Richard McKeon, 'Literary Criticism and the Concept of Imitation in Antiquity' in Ronald S Crane (ed), Critics and Criticism: Ancient and Modern (U Chicago Press 1952) (1936) 147.

89 Ziolkowski (n 72) 296.

90 Horatius (n 80) 323 (ln 240-242) ('Ex noto fictum carmen sequare, ut sibi quivis / Speret idem, sudet multum frustaque laboret / Ausus idem [I would execute a fiction taken from a well-known story, that any body might entertain hopes of doing the same thing; but, on trial, should sweat and labour in vain]').

91 See Macrobius (n 70). 


\section{THE ART OF CENTO AND THE IMITATIO VERGILII}

In mediaeval times, copying and imitation continued to play a central role, even greater than in classical contexts. 'Maro junior! Maro junior!', you may have heard the crowd chanting at a public exhibition of the poet Mavronius sometimes across the sixth or seventh centuries A.D. Acknowledging that request, Mavronius would have improvised a new number of verses from the Virgilian corpus in the form of a cento poem..$^{92}$ Mavronius is believed to be the author of the Cento Virgilianus de Ecclesia. The classical Greek and Latin cento genre was very popular throughout the early Middle Ages. The cento was originally a cloak made of patches. ${ }^{93}$ The term was later used to refer to a form of poetry based on the rearrangement of phrases from other poems, whose final result was a new creative work yielding a meaning different from any of the originals. Apparently, centones resemble modern fanvids that tell new stories using pre-existing material. The so-called Centones Virgilianes came into being in a great number and pieced together phrases, verses, ideas and expressions from Virgil. Mythological, secular and Christian examples survive of both Homeric and Virgilian centos. ${ }^{94}$ A revived interest for cento poetry, and the close genre of mosaic poetry piecing together lines from numerous authors, would characterize Victorian England a few centuries later. ${ }^{95}$ The works of Homer, Euripides, Virgil, Ovid, Cicero and later Petrarch, Shakespeare, Goethe and many others, served as a raw material for cento composition.

Decimus Magnus Ausonius, imperial poet and statesman of late antiquity, had a special role in the history of the genre. In connection with the making of a cento from Virgil, the Cento Nuptialis, Ausonius laid down the rules for composing cento poetry. ${ }^{96}$ In accordance with Ausonius' rules, the cento was supposed to be true to the verse of the original, though some grammatical modification could have occurred. The pieces could be taken either from one poet, or several. A proper

92 See Anscar Zawart, 'History of Classical Education in the Church' in Felix M Kirsch (ed), Classics: Their Hystory and Present Status in Education: A Symposium of Essays (Ayer Publishing 1977) (1928) 55.

93 See Douglas Adams, 'Clothing' in Douglas Adams and JP Mallory (eds), Encyclopedia of Indo European Culture (Taylor \& Francis 1997) 110.

94 See Scott McGill, Virgil Recomposed: the Mythological and Secular Centos in Antiquity (OUP 2005) xv-xvi.

95 See Paul K Saint-Amour, The Copyrights: Intellectual Property and Literary Imagination (Cornell UP 2003) 41-47.

96 See McGill (n 94) 1-21, 92-113. 
cento had to borrow each line from one line or two half-lines of the source. The repetition of two or more lines was to be avoided. Appropriate poetic metre was also to be retained.

Perhaps, the most famous of the cento poems is a biblical pastiche composed of Homeric verses by the Theodosian Empress Eudocia, the Homerocentones or Homerocenta. ${ }^{97}$ Homer is not Eudocia's sole co-author. Most likely, the poem is the result of a collaborative effort spanning about a century. In fact, the poem originated with a Christian cleric named Patricius in the fourth century A.D. and was later expanded by the empress in the fifth century. ${ }^{98}$ Centonism was very often a game, a playful enjoyment of knowledge and words. As in the case of Ausonius, however, the merits of Eudocia's art have recently been expanded. The Homerocenta represents a sophisticated comparative reading of Homer and the Bible as a result of an intertextual association of ideas, words and sounds. ${ }^{99}$

The reuse of the Homeric verses in the Homerocenta - as generally the appropriation of verses in the cento genre - is a form of creative rhapsodic art, tightly correlated with the oral-formulaic tradition and the orality of Greek culture mentioned earlier. Actually, the centonist poet relied on a complete recall of the borrowed poems. The cento poem results from an absolute 'competence' in the text from time to time appropriated. ${ }^{100}$ The expression in the cento poems is by definition completely unoriginal, nevertheless that expression is perhaps the highest exploitation of the knowledge of the original work.

Cento poetry, especially Virgilian cento poetry, served as a learning device in the schools throughout the Middle Ages insofar as it allowed the Virgilian formal and linguistic canon to be adapted to the educational agenda. This is the case, for example, for the closed large-scale parallel to the Homerocenta, Faltonia Betitia Proba's Cento Vergilianus de Laudibus Christi, a Virgilian cento retelling episodes of the Old and New Testament. ${ }^{101}$ Proba, a Roman Christian poet of the fourth century A.D., used cento poetry to adapt Virgil for use in the classroom and circumvent

97 See Eudocia Augusta, Homerocentones (Mark D Usher ed, Teubner 1999).

98 See Mark Usher, Homeric Stitchings: the Homeric Centos of the Empress Eudocia (Rowman \& Littlefield 1998) 3.

99 ibid 144.

100 ibid 10.

101 See generally Elizabeth Clark and Diane Hatch, The Golden Bough, the Oaken Cross: the Virgilian Cento of Faltonia Betitia Proba (Scholars Press 1981). 
educational hurdles discriminating against Christian pupils. ${ }^{102}$ In 362, the Emperor Julian forbade Christian teachers from teaching pagan text to their students. The subtle goal of the policy was to deprive Christian children of an education based upon the learning of the classics, especially Virgil. Proba's cento aimed at maintaining Virgil as the basis of pupils' education, but with the exclusion of paganism and the inclusion of a new Christian plot. Proba's cento was later largely used in education during the Middle Ages, ${ }^{103}$ enjoying a considerable amount of popularity so that Boccaccio included Proba among his list of the most influential woman. ${ }^{104}$

The popularity of Virgil as a subject of appropriation for derivative literary productions belonged to a larger pattern of imitative practices that characterized mediaeval creativity. As Scott McGill has noted, cento form 'became part of a literary world that in various ways treated Virgil as an open work, or as a body of material that could be reworked to yield fresh text'. ${ }^{105}$ At the time, Virgil became the privileged literary model in Western literature. The so-called Imitatio Vergilii would be the mode of poetic writing for several centuries to come. Most attempts at epic poetry in the early Middle Ages were based on borrowings of Virgilian form and language.

However, Virgil himself was a spectacular imitator and rewriter of Homer and other earlier Roman authors. ${ }^{106}$ Macrobius provided a full account of Virgil's borrowings in the Saturnalia. Macrobius quoted 'actual lines of Homer which Virgil has translated almost word for word', 107 and then decided 'to go through the Aeneid from the beginning, book by book'. ${ }^{108}$ Later, Macrobius 'tells us of Vergil's borrowings from the old writers of Rome as well'. ${ }^{109}$ It is an amazing list lasting more than 10 chapters of instances of verbatim duplications, borrowings, translations and rewritings of the Homeric original and Roman authors, such as Ennius, Lucretius, Furius, Lucilius, Pacuvius, Naevius, Sueius,

102 See eg Ian Michael Plant, Women Writers of Ancient Greece and Rome: an Anthology (U Oklahoma Press 2004) 170-171.

103 See Zawart (n 92) 56.

104 See Giovanni Boccaccio, De Mulieribus Claris [Famous Woman] (Virgina Brown trans, Harvard UP 2003) (1374).

105 See McGill (n 94) xviii.

106 See Macrobius (n 70) 290-343 (V3-13) (where Macrobius describes Virgil's adaptations of Latin writers).

107 ibid (V31).

108 ibid 295 (V41).

109 ibid 385 (VI11). 
Varius, Accius and Catullus. ${ }^{110}$ Concerned with the reaction that such a massive amount of Virgil's borrowings might have provoked in his readers, Macrobius endeavoured to plead the case of the greatness of Virgil. In doing so, Macrobius sketched out the principles of imitatio and aemulatio that governed ancient literary creativity:

But I am afraid that in so doing I may afford the unlearned or the ill-disposed an excuse to censure him; for they may charge the great man with the wrongful use of what belongs to another and overlook the fact that the reward of ones' reading is to seek to rival what meet with one's approval in the work of others and by a happy turn to convert to some use of one's own the expressions one especially admires there. For this is what our writers have often done, borrowing both from one another and from the Greeks; and this is what the greatest of the Greeks often did among themselves. ... But if all poets and other writers are allowed to act among themselves in this way, as partners holding in common [haec societas et rerum communio], what right has anyone to accuse Virgil of dishonesty, if he has borrowed from his predecessors to embellish his poems? ?11 $^{11}$

The very principles crystallized by Macrobius will reach far into the creative sensitivity of mediaeval authors. Championed by Virgil, imitation and borrowing strengthen their status as instruments of literary and artistic excellence. If Virgil, the ultimate poetic model, had himself heavily imitated and rewritten his predecessors, then creativity could only progress through imitation. This was the lesson that the ancients, Virgil and Macrobius, left to powerfully resound for the following millennium. Macrobius' Saturnalia, written in the fifth century A.D., heavily influenced later mediaeval literature. It laid down the fundamental principles of literary description as an exercise of imitation and emulation through invention, reordering and different species of modification of previous models. ${ }^{12}$ A large part of the most representative mediaeval and early

110 ibid 290-343 (V3-13), 386-409 (VI1-3).

111 ibid 385-386 (VI12-15). Erasmus of Rotterdam would evoke Macrobius, and the tradition he represented, by starting programmatically his collection of Adages in 1508 with the proverb 'friends hold all things in common' - amicorum communia omnia in the original Latin version. The Adages of Erasmus is a singularly successful product of the emerging printing industry of the early sixteenth century, which looked ahead to the development of copyright and back to the ancient tradition that ideas and knowledge should be universally shared in the spirit of friendship. See Eden Katly, Friends Hold All Things in Common: Tradition, Intellectual Property and the Adages of Erasmus (Yale UP 2001).

112 See Douglas Kelly, The Conspiracy of Allusion: Description, Rewriting, and Authorship from Macrobius to Medieval Romance (Brill 1999) 36-78. 
Renaissance works produced in Latin, French and English were rewrites, following Macrobius' principles of description. In Chapter 2 I will discuss in great detail the prolificness of the art of rewriting in mediaeval epic and romance literature, as a quintessential example of cumulative and collaborative creativity.

\section{ANON, GOD AND AUCTORITAS}

In 1269, two Dominican friars, both going by the name of John of Colonia, claimed authorship of a well-received commentary on the Sentences of Peter Lombard. ${ }^{113}$ The commission called to hear the case and presided over by the eminent scholars and theologians Thomas Aquinas and Siger of Brabant - decided that the work had to bear a neutral title and be dissociated from any of the claimants. Reporting on the case, Aquinas does not provide any evidence of the concept of a text as the special property of its author. Individual property in a text or other creative artefacts was beyond the scope of the mediaeval conceptualization. The creative work, in fact, might have been said to be property of Anon:

The voice that broke the silence of the forest was the voice of Anon. Some one heard the song and remembered it for it was later written down, beautifully, on parchment. Thus the singer had his audience, but the audience was so little interested in his name that he never thought to give it. The audience was itself the singer; 'Terly, terlow' they sang; and 'By, by lullaby' filling in the pauses, helping out with a chorus. Every body shared in the emotion of Anons song, and supplied the story. Anon sang because spring has come; or winter is gone; because he loves; because he is hungry, or lustful; or merry: or because he adores some God. Anon is sometimes man; sometimes woman. He is the ... common voice singing out of doors, He has no house. He lives a roaming life crossing the fields, mounting the hills, lying under the hawthorn to listen to the nightingale. ${ }^{114}$

In these few lines, supposedly part of an unfinished literary history, Virginia Woolf evokes the selfless mediaeval minstrel. Anon, Virginia Woolf continued, 'was a simple singer, lifting a song or a story from other peoples lips, and letting the audience join the chorus'. ${ }^{115}$ Anon

113 See Thomas Aquinas, De Secreto $§ 60$ (1269) as cited in Etienne Gilson, The Christian Philosophy of St Thomas Aquinas (Octagon Books 1983) 417.

114 See Brenda Silver, 'Anon and the Reader: Virginia Woolf Last Essays' (1979) 25 Twentieth Century Literature 356, 382.

115 ibid. 
singing, Anon authorship is a community effort. Anon sang with and for the community. In evoking Anon, Woolf expanded the perception of creativity to a nameless domain, in which individual identity cannot satisfactorily describe authorship. Anon was anonymous. Writing on the anonymous nature of mediaeval creativity, Woolf noted:

[a]nonymity was a great possession. It gave the early writing an impersonality, a generality. It gave us the ballads; it gave us the songs. It allowed us to know nothing of the writer: and so to concentrate upon his song. Anon had great privileges. He was not responsible. He was not self-conscious. He can borrow. He can repeat. He can say what every one feels. ${ }^{116}$

Anonymity becomes the most substantial sign of a social mode of literary production. In this sense, Woolf, and later other scholars such as Margaret Ezell, read mediaeval creativity in terms of social authorship. ${ }^{117}$ Foucault elaborated the same point, noting that the 'author-function is not universal or constant in all discourse' and 'the same types of texts have not always required authors; there was a time when those texts which we now call "literary" (stories, folk tales, epics, and tragedies) were accepted, circulated and valorised without any question about the identity of their author'. ${ }^{118}$

Mediaeval text and creativity, however, were also the property of God. In this respect, mediaeval authorship finds an explanation in the words of Hugh of St. Victor, who wrote that 'the entire sensible word is, so to speak, a book written by the hand of God'.119 In Medieval Theory of Authorship, Alastair Minnis explains that the mediaeval auctor ultimately took his authority from God. ${ }^{120}$ The special connection between God and

\section{6 ibid 397.}

117 See Margaret Ezell, Social Authorship and the Advent of Print (Johns Hopkins UP 1999).

118 Michel Foucault, 'What is an Author?' in Donald Bouchard (ed), Language, Counter-Memory, Practice: Selected Essays and Interviews by Michel Foucault (Cornell UP 1977) (1969) 124-125 (explaining also that any concept of appropriation of a text cannot be used to describe the relationship between a mediaeval author and a mediaeval text. Appropriation of a text, as Foucault explained, is a form of property unknown in the Middle Ages).

119 Hugh of St Victor, Didascalion PL CLXXVI814 as cited in Burt Kimmelman, The Poetics of Authorship in the Later Middle Ages: The Emergence of the Modern Literary Persona (Lang 1996) 180.

120 See Alastair Minnis, Medieval Theory of Authorship: Scholastic Literary Attitudes in the Later Middle Ages (U Penn Press 1988) 10. See also Andrew 
creativity further cements the communal and participatory nature of mediaeval authorship.

God as the author has distant roots in a passage of Plato's Ion. In that passage Socrates remarked that:

the god takes the mind out of [the poets] and uses them as his servants, as he uses oracles and divine prophets: so that their hearers may know it is not they, in whom mind is not present, who tell things of such great value, but the god himself who speaks, making utterance to us through them. ${ }^{121}$

The Greek and Latin practice of invoking the muse to seek poetic inspiration was expression of the idea that the creative act was in need of divine assistance. ${ }^{122}$ Hesiod in the Theogony tells of the Muses summoning him to be a poet on Mount Helicon: 'and they plucked and gave me a rod, a shoot of sturdy laurel, a marvelous thing, and breathed into me a divine voice to celebrate things that shall be and things there were aforetime'. ${ }^{123}$ So, to cite some among the many, Homer began both the Iliad and the Odyssey with invocations to the Muses, Ennius did the same in his Annales, Virgil delivered an imploring call to the Muses at the outset of the Aeneid, and Ovid asked the gods to inspire his 'numbers with celestial heat' in the Metamorphoses. ${ }^{124}$ In the Ars Amatoria, Ovid evoked again the divine spirit possessing the poet at the time of creation and crafted the visual topos of the poet crowned with myrtle:

... and from the myrtle (for she was standing with her locks wreathed with myrtle) she gave me a leaf and few berries. Receiving them I was sensible of the divine influence as well; the sky shone with greater brightness, and all care departed from my breast. While she inspires my genius ... ..$^{125}$

Cicero would reinstate the same idea in De Oratore and De Divinatione. In the Middle Ages and the Renaissance, Cicero's works became the

Hope, 'Plagiarizing the Word of God: Tyndale between Moore and Joye' in Paulina Kewes (ed), Plagiarism in Early Modern England (Palgrave 2003) 93-94.

121 Plato, Ion 535d (Reginald Allen trans, Yale UP 1996).

122 See Penelope Murray, 'Poetic Genius and its Classical Origins' in Penelope Murray (ed), Genius: The History of an Idea (Blackwell 1989) 10-12. 123 Hesiod, Theogony 22-34 (circa 700 B.C.), in The Theogony of Hesiod (Hugh G Hevelyn-White trans, Forgotten Books 2007).

124 Publius Ovidius Naso, I Metamorphoses 2 (Forgotten Books 1936) (circa 8 A.D.).

125 Publius Ovidius Naso, Ars Amatoria 550, in The Art of Love (Kessinger Publishing 2004) (circa 1 B.C.) 88. 
most influential source introducing the doctrine that poetry was composed under the influence of some kind of frenzy or poetic furore. ${ }^{126}$ Similarly, the idea that intellectual creations came through divine revelation seems to be traceable in most of the premodern great civilizations Chinese, Islamic, Jewish and Christian. ${ }^{127}$

The divine nature of authorship is reprocessed in mediaeval terms in light of the concept of authority. The author was seen as receiving auctoritas - authority - to make authoritative statements directly from God.128 The author was to be respected, believed and finally quoted, extracted and imitated. As a consequence of the special relation between creativity, authority and God, the mediaeval evolution of the classical concept of imitatio rested on a premise that reached far beyond the Classics and that joined authors ultimately with God, who was the ultimate source of all creativity and the highest object of imitation - and hence the ... concept of imitatio Christi'. ${ }^{129}$ In this sense, in the Middle Ages plagiarism might have been interpreted also as giving to the people what God has given to the author. ${ }^{130}$

Not surprisingly, in connection with this imitative process joining the author with God's auctoritas, and therefore with the surrounding community, 'writers gain authority less by their originality than by their contribution to an ongoing tradition'. ${ }^{131}$ Likewise in the Roman tradition the quest for excellence overshadowed the importance of originality, in the mediaeval creative process originality is only a variable of a function, whose desired final result is authenticity and authority. Distance from the tradition was perceived as distance from authority, and thus distance from the final goal of creativity. As a result, authorship did not entail verbal

126 See Cicero (n 76) § 2.46.194; Marcus Tullius Cicero, De Divinatione $\S$ 1.37.80, in Cicero: De Senectute De Amicitia De Divinatione With An English Translation (William Falconer trans, Harvard UP 1923).

127 See Carla Hesse, 'The Rise of Intellectual Property, 700 BC-AD 2000:

An Idea in the Balance' (2002) 1312 Daedalus 26, 26-28.

128 See Minnis (n 120) 10.

129 Ziolkowski (n 72) 302-303.

130 See Natalie Zemon Davis, 'Beyond the Market: Books as Gifts in Sixteenth-Century France' (1983) 33 Transactions of the Royal Historical Society 69, 87.

131 Jocelyn Wogan-Browne, Nicholas Watson, Andrew Taylor and Ruth Evans (eds), The Idea of the Vernacular: An Anthology of Middle English Literary Theory, 1280-1520 (Penn State Press 1999) 5. 
inventiveness but rather its opposite. ${ }^{132}$ The Middle Ages coined the very word text out of a textile metaphor to recognize that many mediaeval writings are fabrics that incorporate fibres from earlier writings and preceding traditions. ${ }^{133}$ The process of intertextuality and constant reference to authority and tradition, to which the textile metaphor refers, is a dominating feature of mediaeval creativity.

Through his quest for authority, deeply immerged in the participative nature of the mediaeval creative process, the auctor tends to lose his individual identity to become a pure expression of authority. As Andrew Bennett noted, 'the medieval auctor is seen as effectively, even if not always in practice, anonymous'. ${ }^{134}$ The Middle Ages knew of authorities, such as Aristotle, to name the most famous example, but very few authors. The vast majority of the period's literary production was the work of masters who remained anonymous. ${ }^{135}$ Vernacular writers were very insignificant for their readership, who were interested in the work itself. 136 The text mattered together with the truths that it revealed. Even the great auctores of the past tend to lose any independence from the text; in fact "when medieval writers allude to Augustine or Ovid, the chief association that these authoritative names conjure up is not that of an inspired figure whose genius informs certain texts but that of the texts themselves'. ${ }^{137}$ As these last considerations on anonymity and auctoritas seem to prove, in the end, Anon's songs and God's auctoritas are two sides of the same coin. The role of Anon and God in the production of

132 See Donald Pease, 'Author' in Frank Lentricchia and Thomas McLaughlin (eds), Critical Terms of Literary Study (U Chicago Press 1990) 105-106; Andrew Bennett, The Author (Routledge 2005) 40.

133 See, on the textile metaphor, M Ziolkowski, 'Text and Textuality, Medieval and Modern' in Barbara Sabel and André Bucher (eds), Der unfeste Text: Perspektiven aufeinen literatur- und kulturwissenschaftlichen Leitbegriff (Königshausen \& Neumann 2001) 109-131.

134 Bennett (n 132) 40.

135 See ibid. See also Marcy L North, The Anonymous Renaissance: Cultures of Discretion in Tudor-Stuart England (University of Chicago Press 2003) 40-42 (noting that ' $[\mathrm{b}]$ efore the thirteenth century, authors were viewed as instruments of divine truth and as scribes for a divine author. Names served to authenticate the truth by identifying the human agent of the truth as someone accepted by the church and considered an authority on ecclesiastical issues, but they did not signify the human author's autonomous creativity').

136 See John W Saunders, The Profession of English Letters (Routledge and Kegan 1964) 19-20; Bennett (n 132) 41.

137 Wogan-Browne et al (eds) (n 131) 5. 
premodern creativity seems to overlap. They both are the expression of a collective identity and play a creative role on behalf of the community.

\section{CHAUCER THE COMPILATOR AND SOCIAL TEXTUALITY}

The mediaeval author "is configured as part of a continuum that extends from the simple process of copying at one end to the act of original composition at the other'. ${ }^{138}$ In a well-known commentary on the making of books, the thirteenth-century monk Saint Bonaventure listed four types of makers of books. To a certain extent they loosely resemble the triadic Latin distinction between interpretatio, imitatio and aemulatio. Bonaventure wrote that:

[t]here are four ways of making a book. Sometimes a man writes others' words, adding nothing and changing nothing; and he is simply called a scribe [scriptor]. Sometimes a man writes others' words, putting together passages which are not his own; and he is called a compiler [compilator]. Sometimes a man writes both others' words and his own, but with the others' words in prime place and his own added only for purpose of clarification; and he is called not an author but a commentator [commentator]. Sometimes a man writes both his own words and others', but with his own in prime place and others' added only for purposes of confirmation; and he should be called an author [auctor]. ${ }^{139}$

Even the auctor described by Bonaventure, the nearest to the modern sense of authorship, was understood to be a writer who reshaped material of others for his own purposes, together with writing his own words. ${ }^{140}$ In the model described by Bonaventure, authors were considered closer to translators, compilers or scribes than in modern conceptions of authorship. Although an emergent authorial self surfaces powerfully from the pages of The Canterbury Tales, ${ }^{141}$ even Chaucer expresses the

\footnotetext{
138 Bennett (n 132) 39.
}

139 Bonaventure, 'In Primum Librum Sententiarum' [proem, quaest iv] in Quaracchi (ed), Opera (1882) 14 as cited in John Burrow, Medieval Writers and Their Works: Middle English Literature and its Background, 1100-1500 (OUP 1982) 31 .

140 See Burrow (n 139) 29-30.

141 See Bennett (n 132) 39; Burrow (n 139) 40, 44 (noting that Chaucer, Langland and Gower are poets with names and identities and therefore constitute the first generation of recognizable English writers); Kimmelman (n 119) (producing a detailed discussion of the emergence of the modern literary persona 
common mediaeval attitude that almost everything there is to say has been said. ${ }^{142}$ Nullumst iam dictum quod non sit dictum prius, Terence first noted. ${ }^{143}$ In the Prologue to The Canterbury Tales and other passages, Chaucer presents himself as a mere compiler or translator, who was not the auctor of the books he made nor responsible for the materials he used. ${ }^{144}$ The disclaimer may echo, perhaps, that of Lucian of Samosata. He claimed a millennium earlier his role as a mere mouthpiece of the Muses. He had Hesiod saying in one imaginary dialogue with the poet of old: 'I might tell you that not one of my poems is my own work; all is the Muses', and to them I might refer you for all that has been said and left unsaid.' 145 In the Far East, Confucius would equally note that 'I transmit rather than create; I believe in and love the ancients.' ${ }^{146}$ From Lucian to Confucius and later Chaucer, the auctoritas of the predecessors, as expression of the auctoritas of God, replaced the divine

in the Middle Ages and the emergence of the poetics of the 'I', starting with the Confessions of Saint Augustine, then being fully developed in Marcabru, Dante, Langland and Chaucer). See also Olivia Holmes, Assembling the Lyric Self: Authorship from Troubadour Song to Italian Poetry Book (U Minnesota Press 2000) (discussing the emergence of author-ordered collections - canzonieri in Italy and chansonniers in France - as the 'partial creation of conditions of possibility in which the Romantic concept of transparent authorship could eventually arise'); Colin Morris, The Discovery of the Individual 1050-1200 (U Toronto Press 1972) 10-11 (suggesting that the very notion of self, as traditionally conceived as a Renaissance development, was latently present in mediaeval society); but cf Caroline W Bynum, 'Did the Twelfth Century Discover the Individual?' (1980) 31 J Ecclesiastical History 1, 4, 15 (cautioning against Morris' position and the like and noting that medieval people viewed themselves as members of a corporate body).

142 See Burrow (n 139) 34.

143 Publius Terentius Afer, Eunuchus ln 41 (circa 161 B.C.), in I Terence: The Lady of Andros, The Self-Tormentor, The Eunuch (John Sargeaunt trans, W Heinemann 1918) 238 ('In fact nothing is said that has not been said before'). 144 See Bennett (n 132) 42; Wogan-Browne et al (eds) (n 131) 5; Burrow (n 139) 36-37. See also Sebastian Coxon, The Presentation of Authorship in Medieval German Narrative Literature 1220-1290 (Clarendon Press 2001) 7 (mentioning that many well-known German authors of the mid-twelfth and thirteenth centuries often professed their works to be translations of French and Latin source texts).

145 Lucian of Samosata, Dialogue with Hesiod (circa 160-164 A.D.), in The Works of Lucian of Samosata (Henry Fowler and Francis Fowler trans, Forgotten Books 2007) (1905) 568.

146 See Hesse (n 127) 26 (reporting a saying of Confucius which was included in the Lun-Yii, or Anaclects, compiled in China in the fifth century B.C.). 
inspiration of the Muses. This, however, maintained unaltered the perception of the deep cumulative mechanics of the creative process. As part of this millennial tradition, for Chaucer, therefore, the act of writing was represented by the metaphor of gleaning the harvest of poetry reaped by others:

For wel I wot that folk han here-beforn / Of Makyng ropen [reaped the harvest of poetry], and lad away the corn; / and I come after, glenynge here and there / And am ful glad if I may fynde an ere / Of any goodly word that they han left. ${ }^{147}$

In practice, the roles delineated by Bonaventure often overlapped. The scriptor may have performed the functions of translator, compilator, commentator or even auctor by adding and changing passages deliberately, replacing obscure expressions, omitting passages or adding passages from other sources or his own compositions. Instances of so-called 'scribal interpolation' are common in the case of Chaucer's Canterbury Tales. Prologues, epilogues or tales were added spuriously by those concerned with the transmission of the text that was left in a fragmentary state by Chaucer. ${ }^{148}$ Bonaventure's overlapping roles in the chain of creative literary production blurred the contours of mediaeval authorship, reinforcing its social matrix. In particular, the overlap between the reader and the scribe rendered the participative nature of the writing process even more marked.

The poetic versification in the manuscript environment is one major example of the social history of mediaeval and Renaissance poetic texts. Derek Pearsall noted that in the context of late-mediaeval poetic versification the poetic text is an instrument to be used and not merely read:

Poems are borrowed and their allusions to date and circumstances changed so as to fit a new occasion. Verses are incorporated into love-letters ... stanzas from the common stock are interlaced and reworked; simple pieces, including popular songs are adapted for more ostentatious purposes; famous opening

147 See Geoffrey Chaucer, The Legend of Good Women, Prologue, G version 61-5 as cited in Burrow (n 139) 34.

148 See Burrow (n 139) 32 (describing several single instances where 'scribal interpolation' took place in The Canterbury Tales or in the textual tradition of Langland's Piers Plowman). See Daniel Hobbins, Authorship and Publicity Before Print: Jean Gerson and the Transformation of Late Medieval Learning (U Penn Press 2009) 165-166 (providing a cautionary note, as authors - such as Petrarch, Dante, Chaucer and Hoccleve - frustrated by scribal incompetence, may have tried to control closely the circulation of their works). 
stanzas and striking first lines are pressed into service again and again to launch new poems. ${ }^{149}$

Pearsall elaborated that the poems in the mediaeval manuscript tradition 'are no one's property and the whole notion of authorship is in a way irrelevant'. ${ }^{150}$ The work tended to escape easily authorial control and enter into a world of equally easy appropriation and alteration. Arthur Marotti spoke of social textuality, malleability and textual instability in manuscript culture. ${ }^{151}$ What is viewed as corruption from a modern author-centred perspective was viewed in the manuscript culture as transformative elaboration, generally accepted and often welcomed by the original author. In this regard, Marotti noted that '[i]n fact, some authors expected and even welcomed the changes that the recipients of their works brought to them, acknowledging the possibility that modern textual scholarship has been reluctant to admit, that text might (accidentally or deliberately) be improved by individuals other than the original writer'. ${ }^{152}$

Publishing practices before print were prompting a phenomenon of social textualization. Publishing, if the term can be employed at all before print, was characterized by an ongoing process. ${ }^{153}$ Publication started with the initial delivery of the text, as in the case of an oral 'pronunciation'. In a second moment, the text already in circulation could undergo the author's corrections and revisions. Finally, publication allowed for the participation of the bookmakers - such as scribes, illuminators and so on - and readers who made changes to the text they copied and reproduced. In this respect, authors before print had a limited control of their text and 'once a text left the author's control, readers too could add their own voices to shape the text in ways the author never imagined'. ${ }^{154}$ Hence, the text before print is a permanent unfinished

149 Derek Pearsall, Old and Middle English Poetry (Routledge and Kegan Paul 1977) 221.

150 ibid.

151 See Arthur Marotti, Manuscript, Print, and the English Renaissance Lyric (Cornell UP 1995) 135-159 (reporting scribes exercising authorial functions by adding lines or stanzas to the poems they were copying, or poems that continued to mutate in the pursuit of their transmission in both manuscript and print, or different poems that conflated in whole or in part to create new poetic units).

152 ibid.

153 See Elizabeth Eisenstein, The Printing Press as an Agent of Change: Communications and Cultural Transformations in Early Modern Europe (CUP 1980) 11.

154 Hobbins (n 148) 154. 
business, whose writing became the effort of many endlessly chiselling and adapting the text as a sole author. Jean Gerson - chancellor of the University of Paris across the fourteenth and fifteenth centuries and one of the most prominent scholars and theologians of his time - wrote in the tract In Praise of Scribes of Healthy Doctrine that a writing can endure for a thousand years, whether 'on its own or through the multiplying of exemplars'. ${ }^{155}$

The common character of both the scribe and the author was to participate in an ongoing intellectual tradition connected to past authorities. In this sense, mediaeval authorship 'was more likely to be understood as participation in an intellectually and morally authoritative tradition within which ... a writer might fill one of several roles, copying, modifying and translating, as well as composing'. ${ }^{156}$ Thus in the mediaeval period, creativity was largely conceived as a participatory process, as opposed to the modern post-Romantic individualistic perception. In the Middle Ages, creativity seemed to entail principally a process of slow augmentation of 'the knowledge and wisdom of humanity'. ${ }^{157}$ In the end, the goal of mediaeval creativity is what the moderns would call the public domain. An alternative origin of the word 'author' may confirm this construction of mediaeval creativity. In addition to the ancient Greek av่tós, the most accredited etymology of 'author' is the Latin verb augêre - augmenting, increasing or making to grow. ${ }^{158}$ An auctor would be one who makes a thing - and in this case knowledge - 'grow'.

Setting aside etymological considerations, creativity was an inclusive medium in mediaeval times. The mediaeval author was a cell of a breathing organism, the mediaeval community, and creativity was an instrument to strengthen the author's appurtenance to the community. Thus, in the mediaeval period, creativity was largely conceived as a participatory process, as opposed to the modern Romantic individualistic perception. Creativity in the Romantic sense is an exclusive medium, empowering the individual to stand out from the community. But as will be discussed later, the idea of inclusivity in the discourse over creativity has regained momentum. In the digital environment, there is renewed

155 Jean Charlier de Gerson, In Praise of Scribes of Healthy Doctrine (1423) as cited in Hobbins (n 148) 166.

156 Wogan-Browne et al (eds) (n 131) 4-5.

157 See Burrow (n 139) 34.

158 See eg Eric Partridge, Origins: A Short Etymological Dictionary of Modern English (Routledge 1958) 178-179. 
emphasis on community, participation, and mass and cumulative production. Therefore, creativity in the digital age may seek again a paradigm of inclusive rights, rather than exclusive rights, as I will argue at the end of this work.

\section{SUA MANO AT THE RENAISSANCE WORKSHOP}

As Hauser noted, at least until the early Renaissance, the starting point of artistic production 'is to be found mostly not in the creative urge, the subjective self-expression and spontaneous inspiration of the artist, but in the task set by the customers'. ${ }^{159}$ This in turn promoted a peculiar notion of authorship that departed substantially from the modern and emphasized collaborative practices. Although the relationship between authors and Renaissance princes and patrons was always fluctuating, ${ }^{160}$ art historians have highlighted the decisive role exercised by patrons in producing a work of art. ${ }^{161}$ Michael Baxandall noted that in the social and creative relationship between patrons and artists, the former controlled the subject, commonly by means of an agreed drawing, materials and delivery date of the work of art. ${ }^{162}$ Surviving contracts give a precise account of the extent of the control of the patrons over the artists' work. ${ }^{163}$ Actually, the patron defined the subjects of artistic artefacts in

159 Arnold Hauser, II The Social History of Art (Routledge 1999) (1951) 35 [hereinafter Hauser II].

160 See Martin Gosman, 'Princely Culture: Friendship or Patronage?' in Martin Gosman, Alasdair Macdonald and Arjo Vanderjagt (eds), Princes and Princely Culture 1450-1650 (Brill 2003) 11. See also Peter Burke, The Italian Renaissance: Culture and Society in Italy (Princeton UP 1999) 75-84, 107-110; cf Evelyn Welch, Art and Society in Italy 1350-1500 (OUP 1997) 114 (noting that 'few artists could afford to work only according to their own ideas and few patrons had, or even wanted, total control over the finished product; the majority of relationships were somewhere in between these extremes'); Hauser II (n 159) $46-48$.

161 See eg Martin Wackernagel, The World of the Florentine Renaissance Artist: Projects and Patrons, Workshop and Art Market (Alison Luchs trans, Princeton UP 1981) (1938); Michael Baxandall, Painting and Experience in Fifteenth-Century Italy (OUP 1972); but see Creighton Gilbert, 'What Did the Renaissance Patron Buy?' (1998) 51 Renaissance Quarterly 392.

162 See Baxandall (n 161) 1-5.

163 See Burke (n 160) 104-106; Michelle O'Malley, 'Subject Matters: Contracts, Designs, and the Exchange of Ideas between Painters and Clients in Renaissance Italy' in Stephen J Campbell and Stephen J Milner (eds), Artistic 
minute detail through contractual agreements or more informal arrangements. Only some rare exceptions, such as Michelangelo or Leonardo, usually maintained full artistic independence. In some instances, famous humanists, such as Politian, Pietro Bembo and Annibale Caro, served as intellectual middlemen between the patron and the author, providing detailed programmes for the work of art to be realized. Politian, for example, perhaps served as a humanist adviser for the mythological paintings of Botticelli and Michelangelo's relief of The Battle of the Centaurs. ${ }^{164}$ A statement made by Titian may prove the considerable influence of the patron in art making:

[t]he greatness of art among the ancients was due to the assistance they received from great princes content to leave to the painter the credit and renown derived from their own ingenuity in commissioning pictures ... I shall, after all, have done no more than give shape to that which received its spirit - the most essential part - from Your Excellency. ${ }^{165}$

In flattering his patron, the Duke of Ferrara, Titian restated a tradition that has long roots in ancient and mediaeval times. In very similar terms to those of Titian, Rudolf von Ems, a leading German poet of the mid-twelfth century, refers to the King's commission as the origin of his authorship:

[m]y beloved lord, for whom I have toiled away at this book with my composition and - with God's aid - want to continue to do so, if God grants me the years to do him this service; King Conrad, that is, child of the emperor, who has commanded me and who deigned to commission me, by request, to compose the tales for his sake ... . He instructed me to translate all of the true things into German verse on his account, so that the great profit of his reward would relieve me of much of my suffering .... . ${ }^{166}$

Exchange and Cultural Translation in the Italian Renaissance City (CUP 2004) 17-37, 18, 32 .

164 See Aby Warburg, The Renewal of Pagan Antiquity: Contribution to the Cultural History of the European Renaissance (Getty Publ 1999) (1932) 95. See also Burke (n 160) 110-111 (reporting many other examples).

165 See Joseph Crowe and Giovanni Cavalcaselle, I The Life and Times of Titian: With Some Account of his Family (John Murray 1881) 181.

166 Rudolf von Ems, Weltchronik 21656-21689 as cited in Coxon (n 144) 86. In a work of Konrad von Würzburg, the dedication to the patron takes the form of a virtual abdication of the author's role: 'Johannes von Arguel, child of the daughter of the Winharts, created the conditions in which [Pantaleon's] miracles could take such beautiful poetic form By the reward of his payment he brought them to light in the German language from Latin, in order for people to 
As in mediaeval times, the term 'fecit' was often still used to refer to Renaissance patrons. Very often, the person who commissioned the work was considered its maker as was the 'artisan' who manufactured it. ${ }^{167} \mathrm{~A}$ call, however, has been made to draw attention to the role and intentions of the artist. According to Ernst Gombrich, Renaissance artistic innovation emerged from the interaction between patrons and artists. ${ }^{168}$ In the Renaissance, the work of art was thought to be the patron's, who had conceived it. Yet, it sprang from the artist's understanding of the wishes and needs of the patrons. In contrast with the Romantic notion of an artist isolated from society, Renaissance art was the result of a social relationship between patrons and artists.

The collaborative exchange between authors and patrons was by no means limited to visual arts. As Peter Shoemaker has discussed, court ballet, for example, was a paradigmatic product of collaborative authorship between authors and patrons, as well as many forms of occasional writings. ${ }^{169}$ In court ballet, the patron and the writer selected the subject collaboratively. The principal poet drafted the broad outline of the performance, and one or more other poets often wrote the actual verses recited by the courtiers. ${ }^{170}$ The writer was often not expressing himself in his own voice. In fact, the author was giving voice to others' thoughts, or expressing the desire of others to commemorate or exalt special circumstances. In this respect, the collective and collaborative nature of authorship was entangled with the occasional nature of writing. Although the

understand clearly through this work that he [Pantaleon] can dispel grief. All those who hear this poem, and anyone who hears his martyrdom, should wish for the salvation of the man who promoted this work' Konrad von Würzburg, Pantaleon 2140-2153 as cited in Coxon (n 144) 108.

167 See Patricia Lee Rubin, Images and Identity in Fifteenth-Century Florence (Yale UP 2007) xii. See also Hauser (n 12) 76 (noting that often the predicate 'fecit' added to a name in an inscription meant the person who commissioned the work, rather than the manufacturer).

168 See Ernst Gombrich, 'The Renaissance Conception of Artistic Progress and Its Consequences' in Norm and Form: Studies in the Art of the Renaissance (Phaidon 1966) (1955). See also John Stephens, The Italian Renaissance: the Origins of Intellectual and Artistic Change before the Reformation (Longman 1990) 86; F W Kent and Patricia Simons, 'Renaissance Patronage: An Introductory Essay' in F W Kent and Patricia Simons (eds), Patronage, Art and Society in Renaissance Italy (Clarendon Press 1987) 17-18.

169 See Peter Shoemaker, Powerful Connections: the Poetics of Patronage in the Age of Louis XIII (U Delaware Press 2007) 72-73, 102-103.

170 ibid (mentioning the notorious Ballet de Bacchanales (1623) which included contributions from a large number of poets, including Théophile de Viau writing verses for his patron the Duc de Montmorency). 
Romantics and post-Romantics considered serious poetry compromised by the circumstantial, specific and external occasion, ${ }^{171}$ the occasional verse (vers de circumstance) dominated much pre-Romantic poetry. In occasional writing, poetry is formed and informed by more sources than the single individuality of a particular consciousness. Therefore, modern notions of authorship are hardly applicable to these creative products. As late as the seventeenth century, selection of arguments, ordering of arguments and the arrangements of words were functions often fulfilled by different subjects, rather than a sole creator. In this sense, originality had a less relevant role in the premodern creative process, while collaboration and appropriation were often the rule. As Shoemaker observed, 'the work of writing, from the Middle Ages through much of the eighteenth century, was largely a matter of reworking or putting a stylistic twist on an old idea, rather than novelty'. ${ }^{172}$ Indeed, the same notions were to be applied to any form of occasional works, such as commissioned paintings or letters composed by secretaries. ${ }^{173}$ In the 'workshop atmosphere' that characterized seventeenth-century writing, it was not unusual that the patrons were designated as the true authors of works physically written by others and that, later, an author could inversely reappropriate a patronage text by publishing it in single author's volumes or collective anthologies and investing perhaps the text with a new meaning. ${ }^{174}$

In any event, it cannot be undermined that the framework of political ideology put a strain on the creative process. ${ }^{175}$ Artistic creations and art patronage were powerful instruments to strengthen and consolidate the positions of princes and those in power. In his Prince, Machiavelli noted that '[a] prince must also show himself a lover of merit, give preferment to the able, and honour those who excel in every art'. ${ }^{176}$ To the patrons,

171 See George Wilhelm Friedrich Hegel, Aesthetics: Lectures on Fine Art (T M Knox trans, Clarendon Press 1975) 996. See also Predrag Matvejevitch, La Poésie de circonstance (Nizet 1971) 47.

172 Shoemaker (n 169) 101.

173 ibid 94-100.

174 ibid 108-109 (mentioning the Letters published in 1624 by Guez the Balzac in a collection and written earlier in 1619 for the duc d'Épernon).

175 See Erwin Panofsky, Studies in Iconology: Humanistic Themes in the Art of the Renaissance (OUP 1939) and Meaning in the Visual Arts: Papers in and on Art History (Doubleday 1955) (interpreting the meaning of a painting largely by reference to the programme, given to the artist by the patron, that could be deciphered within it).

176 Niccolò Machiavelli, The Prince and the Discourses (Luigi Ricci trans, The Modern Library 1950) 85. 
the artist is no more than an instrument that should promote the interest of the socio-political system. Cultural production cannot fail to echo the ideological programme and the distortion of cultural propaganda. Conformity to the norms of society is the rule, contestation of the social norms and the political ideology of the patrons leads to exclusion or prosecution. As Martin Gosman noted, court culture is ephemeral because "cultural production is serviceable and essentially based on the catalogue of idées reçues which, in the relevant context, function as a kind of ideological framework'. ${ }^{177}$ Additionally, often the desired work of art, and even the artist's modus operandi, was constrained within the framework of the political ideology. To this end, Isabella d'Este gave detailed literal and technical prescriptions to Perugino concerning the Battle of Chastity and Lasciviousness and Charles IX imposed on Ronsard, the most outstanding Pléiade-poet, the décasyllabe of the French chanson de geste, rather than the alexanderin chosen by the author, for the epic poem Franciade. ${ }^{178}$

However, besides the author-client relationship, collaborative practice in mediaeval and Renaissance creativity was also present in an additional more eminent form. The work in the mediaeval and Renaissance bottega - or workshop - was organized around a small group of men producing artistic artefacts in collaboration. ${ }^{179}$ The habits of collaboration ranged from the sharing of expenses for rent and equipment to insurance against illness and defaulting clients, to division of labour inside the shop and cumulative and collaborative work on the same painting or other artistic products. ${ }^{180}$ As Hauser noted, 'until the end of the fifteenth century the artistic labour process still takes place entirely in collective forms'. ${ }^{181}$ In the early Renaissance, 'the work of art is not yet the expression of an

\footnotetext{
177 See Gosman (n 160) 28.

178 ibid 8, 23-24; Stephens (n 168) 68-72 (discussing in detail the correspondence between Isabelle d'Este and Perugino).

179 See Burke (n 160) 51-75; Welch (n 160) 81-91; Hauser II (n 159) 48-49.

180 See Burke (n 160) 64 (noting that artists could work on the same paintings together or consecutively, as, for example, in the Ovetari Chapel at Padua, where Pizzolo with Mantegna, and Antonio da Murano with Giovanni d'Alllemagna worked on the frescos in pairs, or in the case of two paintings made by Pontorno from cartoons by Michelangelo or a statue of St Francis by Pietro Torrigiani finished by Michelangelo); Welch (n 160) 91-100.

181 Hauser II (n 159) 48. Cf Robert Merges, 'From Medieval Guilds to Open Source Software: Informal Norms, Appropriability Institutions, and Innovation' (2004) Conference on the Legal History of Intellectual Property Working Paper
} 14. 
independent personality, emphasizing his individuality and excluding himself from all the extraneous influences' ${ }^{182}$

The collaborative furnace of the mediaeval and Renaissance workshop, together with the collaborative relationship between authors and clients, forged attitudes towards originality and copying still very different from those of our time. ${ }^{183}$ In a thoroughly researched book, Richard Spear recounts an anecdote that perfectly illustrates those Renaissance mechanics of creativity. ${ }^{184}$ Guido Reni was a very successful artist working in Rome across the fifteenth and sixteenth centuries, formerly the most famous pupil of the Carracci's Bolognese academy. Pope Paul V Borghese commissioned Reni to decorate one chapel of the Quirinal Palace. In discussing the terms of the commission with Reni, who was already a favourite of Paul V, the Pope clearly spelled out that the work was to be carried out di sua mano, meaning by Reni's hand. One day the Pope visited Reni's studio and, to his great dismay, caught one of Reni's assistants, Lanfranco, painting some draperies of certain figures. Outraged, Paul V left the studio, noting that it was now clear that Reni attached to the commission as much money as he did little work. As reported by an historian of the time, when Reni visited the Pope the next day,

contrary to his usual custom, [he] genuflected (which earlier he had been forbidden to do) and humbly requested permission to speak. 'Beatissimo padre', he went on to say, 'the drawing, sketching, and background painting are not the things that make up the work. They are just like a simple contract that, before you place your hand on it and sign it, is worthless. In addition to the ideas and the designs that are mine, I go over, finish and redo everything in a way that, if a work given to me does not turn out to be by my hand, I will be content to incur your indignation, which would bring me as much grief as, so to speak, the loss of a thousand lives'. ${ }^{185}$

In Reni's opinion, an original 'was any work that he designed and approved of, regardless of whether retouchings were added to paintings

\footnotetext{
182 Hauser II (n 159) 48.

183 See David Quint, Origin and Originality in Renaissance Literature: Versions of the Source (Yale UP 1983) (discussing the counterfeit and the original in Renaissance art and literature).

184 See Richard Spear, The 'Divine' Guido: Religion, Sex, Money, and Art in the World of Guido Reni (Yale UP 1997).

185 Carlo Malvasia, The Life of Guido Reni (Penn State UP 1980) as cited in Spear (n 184) 253.
} 
that were not literally, "by his own hand" ${ }^{186}$ In similar fashion, in a letter of 12 May 1618, Rubens responded to the complaint of Dudley Carleton, who did not want retouched student works, by insisting that the retouched works 'are not simple copies but are so well retouched by my hand that it would be difficult to tell them from the originals'.187 In sculpture the same issues arose. When Colbert commissioned the equestrian statue of Louis XIV from Bernini, the sculptor was told to do the head himself, but to go over everything made by his assistants in such a way that it could be said that it was truly a work by Bernini. ${ }^{188}$ The notion of originality in the context of Renaissance artists' studios therefore expands well beyond modern boundaries into a collaborative and collective domain. ${ }^{189}$

Additional complexities in grasping the attitude towards originality in the Renaissance are connected with the tradition of making copies out of the artist's own works as well as works of other artists. In the first case, artist studios' practice blurred substantially the concept of originality by the traditional reliance on the work of assistants and students. As reported by Richard Spear, "many paintings were replicated, but only a few were fully autograph; more were "retouchings" (ritocchi) by [the Master] of studio version, and a still greater number were copies by assistants'. ${ }^{190}$

The patrons attempted to secure the highest authenticity and originality of the work by introducing contractual clauses that obliged the Master with different levels of involvement. Fatto di sua mano - 'made by one's hand' - was a technical term in patron-artist contracts, supposedly intended to signify that the work was to be made by the Master himself. However, this was not usually the case, as the episodes of Reni and Rubens earlier mentioned may suggest. In fact, authors have argued that

\footnotetext{
186 Spear (n 184) 253.

187 Letter from Rubens to Dudley Carleton (12 May 1618) as cited in Spear (n 184) 253.

188 See Rudolf Wittkower, 'The Vicissitudes of a Dynastic Monument:
} Bernini's Equestrian Statue of Louis XIV' in Millard Meiss (ed), De Artibus Opuscula XL: Essays in Honor of Erwin Panofsky (NY UP 1960) 521 (noting also that, afraid of the sculptors' studio practice of the time, Colbert instructed Bernini to make a monument similar to the recently completed Constantine, yet different enough that none could say that it was a copy).

189 See Wade Saunders, 'Making Art, Making Artists' (1993) 81 Art in America 70 (concluding, after several interviews with contemporary artists, that, whether collaborative work is present in contemporary studio practice, most artists prefer to suggest that the work was created personally for fear of diminishing the authenticity and value of the work).

$190 \quad$ Spear (n 184) 253. 
'made by one's hand' might only have implied moral responsibility, rather than autograph status. ${ }^{191}$ Most likely, the term 'by his hand' did not refer to the exclusive hand of the Master but only guaranteed a work that was supervised and finally 'retouched' by the Master. In fact, although the signing of paintings used to be taken as a mark of emerging individualism, when the head of the workshop signed a work in the Renaissance, it did not even mean that he had made it with his own hand, but only that the work met the standards of the workshop. ${ }^{192}$ In contrast, a much greater participation of the Master in executing the commission was implied by the use of the technical contractual term di sua propria mano - 'by his own hand'. As an example, a contract entered into by the Company of the Purification in 1461 with Benozzo Gozzoli spelled out that the artist was to paint 'di sua propria mano the figures, decorations, and each and every part, so that no other painter intervenes, whether in the predella or any other part of it' ${ }^{193}$

From the mid-fifteenth century, entire workshops were organized to produce copies on a large scale, such as the workshop of the so-called 'Lippi and Pesellino Imitator'. ${ }^{194}$ In a time span of roughly 40 years, this reproductive enterprise produced more than 160 paintings derived from the paintings of Fra Filippo Lippi and Francesco Pesellino. In the case of the Lippi and Pesellino Imitator the degree of precision between the originals and the copies was very high, perhaps as a result of following a copying practice known as retrahere - to draw again - that consisted in the use of 'pin-pricked drawings used like stencils to replicate the design'. ${ }^{195}$ Often, however, contracts between painters and patrons included a modo et forma clause, providing for a more standard kind of reproduction identified as similitudine, which called for paintings to be made in the manner of other works. ${ }^{196}$

191 See Charles Seymour, Jr, "Fatto di sua mano": Another Look at the Fonte Gaia Drawing Fragments in London and New York' in Antje Kosegarten and Peter Tigler (eds), Festschrift Ulrich Middeldorf (de Gruyter 1968) 93-105.

192 See Burke (n 160) 63-64.

193 Spear (n 184) 254.

194 Megan Holmes, 'Copying Practices and Marketing Strategies in a Fifteenth-Century Florentine Painter's Workshop' in Stephen Campbell and Stephen Milner (eds), Artistic Exchange and Cultural Translation in the Italian Renaissance City (CUP 2004).

195 ibid 41.

196 See Michelle O'Malley, 'The Business of Art Contracts and Payment Documents for Fourteenth and Fifteenth-century Italian Altarpieces and Frescoes' (PhD Dissertation, University of London 1994) 150-151. 
In a letter to Paul Fréart de Chantelou, Nicolas Poussin discussed the rampant practice of copying in the sixteenth century:

I have thought a thousand times about the too little love, care and clarity that our professional copyists bring to what they imitate and of the price they ask for their daubs. And I have marvelled altogether how so many people enjoy them. It is true that, seeing beautiful things and not being able to own them, one is obliged to content oneself with copies, even badly made, which, in truth, could diminish the name of many good painters, if it weren't that their originals are viewed by many who know well the extreme difference that exists between them and the copies. But those who do not see anything except a bad imitation easily believe that the original is not a great thing. ${ }^{197}$

However, there were mixed feelings towards copies. The chancellor of Duke Vincenzo I of Mantua refused a group of copies by noting in a letter that the copies were 'not suitable for Your Highness, who has no need for copies but rather desires originals by good hand that are worthy to stand among the many others Your Highness has by the most excellent painter'. ${ }^{198}$ In contrast, the inventories of collections of paintings of many important patrons, such as Cardinal Federico Borromeo or Cardinal Francesco Maria del Monte, divided the paintings also according to whether they were 'originals by artist of importance' or 'originals by less famous painters' and 'copies made with diligence'. ${ }^{199}$ In some other instances, the inventory depended only on two designations, 'by hand of' and 'copy of'. Sometimes the copies were even accredited to be able to surpass the original. For example, part of the early fame of Guido Reni was attributed to a copy he made of Raphael's Santa Cecilia, which was praised by experts of the time for having 'a mellowness and softness that the original lacked'. ${ }^{200}$ Also Duke Cosimo de' Medici valued greatly copies of high quality. De' Medici is reported to have said that in the case of copies that deceive against the original 'the copy should be preferred to the original because it contained both skills, that of the originator and that of the copier'. ${ }^{201}$ As David Quint noted - telling the story of a Michelangelo's counterfeit of an ancient sleeping Cupid - if the imitator

197 Letter from Nicolas Poussin to Paul Fréart de Chantelou (12 January 1644) as cited in Spear (n 184) 266.

198 See Spear (n 184) 267.

199 ibid.

200 Malvasia, The Life of Guido Reni as cited in Spear (n 184) 269-270.

201 Giulio Mancini, Considerazioni sulla Pittura (Accademia Nazionale dei Lincei 1956) (1619) 135. 
had come up to his model, the counterfeit would have been equal in worth to the original. ${ }^{202}$

Together with pure reproductive copying, adaptations, modifications and alterations of previous works were commonplace for authors and commonly commissioned by their patrons. This practice often consisted in plain remix or mash-up of other works, where faces and figures were lifted from old to new paintings. Cardinal Federico Borromeo had Raphael's profane images transformed into sacred subjects by Antonio Mariani. Cardinal Borromeo explained the mechanics of this process of adaptation as follows:

From the threshold [of the gallery] is seen a Magdalena, whose head was based on that of a goddess painted in Rome by Raphael. It is a work by a painter of ours to whom I suggested to change the famous profane images into sacred ones in this way. He represented the saint in the act of raising into the air ... . Actually I would have wished a little more modesty in her face, but it was impossible to change the features of the original. Near Raphael's Magdalene (for thus it can be called) there is a Hercules ... painted by the same artist in the Chigi Palace. Our painter has added to it an angel with a book, so that Hercules can ... represent St. Matthew. I am so very pleased at having been able to get into the Museum most of the Roman works, thus adapting them to pious use. ${ }^{203}$

\section{SHAKESPEARE, FEATHERS AND CROWS}

Robert Greene described his younger contemporary, Shakespeare, as 'an upstart crow beautified with our feathers'. ${ }^{204}$ Resenting Shakespeare for dipping too far into his Pandosto for The Winter's Tale, ${ }^{205}$ or perhaps

202 See Quint (n 183) 1-3.

203 Federico Borromeo, Musaeum Bibliothecae Ambrosianae (1625) as cited in Pamela Jones, Federico Borromeo and the Ambrosiana: Art and Patronage in Seventeenth-Century Milan (CUP 1993) 138-139.

204 Robert Greene, Groatsworth of Wit: Bought with a Million of Repentance Describing the Folly of Youth, the Falsehood of Make-Shift Flatterers, the Misery of the Negligent, and Mischiefs of Deceiving Courtesans Written Before his Death, and Published at his Dying Request (B E Blackwell 1919) (1592) 83. See also eg Terence Schoone-Jongen, Shakespeare's Companies: William Shakespeare's Early Career and the Acting Companies, 1577-1594 (Ashgate Publishing 2008) 18-21 (discussing the interpretation of Greene's passage).

205 See Lindey (n 32) 75. 
after assisting in a performance of Henry VI, ${ }^{206}$ Greene warned other writers to abandon playwriting because Shakespeare 'with his Tiger's heart wrapped in a Player's hide, supposes he is an absolute Ioannes fac totum, is in his own conceit the only Shake-scene in the country'.207

And, indeed, Shakespeare was, in modern terms, a plagiarist on a vast scale. According to Malone, out of 6,033 lines of Parts I, II and III of Henry VI, Shakespeare copied 1,771 verbatim and paraphrased 2,373.208 Whole passages of Antony and Cleopatra, to take just one example, were line-by-line versifications of historical prose works. ${ }^{209}$ Again, in The Tempest, Gonzalo's description of the ideal state was a word-for-word transposition of Michel de Montaigne's essays Of the Cannibals, as translated by John Florio in 1603.210 In his essay, Montaigne wrote:

it is a nation ... that hath no kind of traffic, no knowledge of letters, no intelligence of numbers, no name of magistrate, nor of politic superiority; no use of service, of riches, or of poverty; no contracts, no successions, no partitions, no occupations but idle; no respect of kindred but common, no apparel but natural, no manuring of land, no use of wine, corn or metal.211

Perhaps with Florio's translation of Montaigne's essays at his elbow, Shakespeare had his character proclaiming:

I'd the commonwealth, I would by contraries / Execute all things; for no kind of traffic / Would I admit; no name of magistrate; / Letters should not be known; no use of service / Of riches or of poverty; no contracts / Succession; bound of land; tilth, vineyard, none; / No use of metal, corn or wine or oil; / No occupation; all idle men, all. ${ }^{212}$

206 See Ilya Giliov, The Shakespeare Game: The Mystery of the Great Phoenix (Algora Publishing 2003) 120 (and, in fact, Greene's passage seems to parody a quotation in Henry VI Part III: 'O tiger's heart wrapped in a woman's hide').

207 Greene (n 204) 83-85.

208 See Lindey (n 32) 75.

209 See William St Clair, 'Metaphors of Intellectual Property' in Ronan Deazley, Martin Kretschmer and Lionel Bently (eds), Privilege and Property: Essays on the History of Copyright (Open Book Publishers 2010) 384.

210 See Samuel Delany, Longer Views: Extended Essays (Wesleyan UP 1996) 225; Lindey (n 32) 74-75.

211 Michel de Montaigne, 'On Cannibals', in Montaigne's Essays (John Florio trans, 1603) (1580) I30.

212 William Shakespeare, 'The Tempest' 21152-173, in The Dramatic Works of Shakspeare: from the Text of Johnson and Steevens (Wardle 1836) 8. 
Modern copyright laws might conceivably have stifled at birth almost all of Shakespeare's works because they 'stole' from Raphael Holinshed and Edward Hall's prose histories of England, Thomas North's translation of Plutarch, Arthur Brooke's poem Romeo and Juliet, Chapman's Homer, Golding's Ovid, and many others. ${ }^{213}$

As was the case with Homer, some have even questioned whether Shakespeare ever existed. ${ }^{214}$ This suggestion is fascinating because Shakespeare would be a back-formation, the last anonymous author, and the synthesis of them all. Shakespeare would be the name of Anon on the last day of his life. Anon-Shakespeare would be the synthesis of a millennium of popular culture, transitioning from orality to writing through the Middle Ages and the Renaissance. Shakespeare would represent Platonic and Aristotelian mimēsis, the successful achievement of the Roman quest for perfection and excellence, and the testament of the inclusive, cumulative and collaborative notion of premodern creativity, to be read on the day Anon is killed by the raising demons of possessive individualism.

Regardless of the identity of the Immortal Bard, Shakespeare's plagiarism was not an isolated case in early modern England. Extensive - and unacknowledged - appropriations were commonplace, especially in drama, though widespread in all literary fields. ${ }^{215}$ The Mock Astrologer of Dryden is a manifesto for proud plagiarism and self-conscious reuse of others' plots and stories. In the play's prologue, Dryden laid down his own apologia of plagiarism:

I am taxed with stealing all my plays ... [i]t is true that whenever I have liked any story in a romance, novel or foreign play, I have made no difficulty, nor

213 See Nick Groom, 'Forgery, Plagiarism, Imitation, Pegleggery' in Kewes (ed) (n 120) 79 .

214 See eg James Shapiro, Contested Will: Who Wrote Shakespeare? (Simon and Schuster 2010) (recounting among many doubters Freud, Henry James, Mark Twain and Helen Keller).

215 See eg Paulina Kewes, Authorship and Appropriation: Writing for the Stage in England 1660-1710 (OUP 1998); Paulina Kewes, 'A Play, which I Presume to Call Original: Appropriation, Creative Genius and EighteenthCentury Playwriting' (2001) 34 Studies in the Literary Imagination 17. See also Lisa Richardson, 'Plagiarism and Imitation in Renaissance Historiography' in Kewes (ed) (n 120) (describing a long tradition of verbatim borrowing and imitation in English historiographers). 
ever shall to take the foundation of it, to build it up, and to make it proper for the English stage'. ${ }^{216}$

In writing his play, Dryden had drawn on Pedro Calderón de la Barca's El Astrologo Fingido and Thomas Corneille's Le Feint Astrologue, from which, by Dryden's own admission, he 'rejected some adventures ... heightened those which [he had] chosen; and ... added others which were neither in the French or Spanish' ${ }^{217}$ In a quest for perfection among giants of the stage, Calderón's, Corneille's and Dryden's plays each imitated their predecessor's, each separated by 20 years (Calderón published in 1623, Corneille in 1652 and Dryden in 1668). This very successful pattern of reuse would be impossible under modern copyright policies.

Borrowing flourished in sixteenth-century England to such an extent that Sir Sidney Lee noted ' $[\mathrm{t}] \mathrm{he}$ full story of the Elizabethan sonnet is, for the most part, a suggestive chapter in the literary records of plagiarism'. ${ }^{218}$ Even the greatest of the Elizabethan sonneteers transcribed the language and sentiments of popular French and Italian poetry. Plagiarism was not at all considered a creative mischief. As Harold White noted, '[n]ot only were Englishmen from 1500 to 1625 without any feeling analogous to the modern attitude toward plagiarism; they even lacked the word until the very end of that period'.219

In the seventeenth and early eighteenth centuries, plagiarism was also a consequence of the manuscript culture that still resisted the definitive surrender to print. ${ }^{220}$ The late Renaissance and the early Enlightenment were the age of the 'commonplace book', manuscript miscellanies and coterie circulation. Particularly in England, the practice of any aspiring authors or scholars of copying and arranging passages from one's reading - so-called 'commonplacing' - in a 'commonplace book' still promoted a cultural environment of considerably open and unacknowledged reuse..$^{221}$ Jonson, Pope, Dryden and Milton had all to face later accusations of

216 John Dryden, 'Preface to the Mock Astrologer' (1671) in Edmond Malone (ed), The Critical and Miscellaneous Prose Works of John Dryden, Now First Collected (Baldwin and Son 1800) 202.

217 ibid 203.

218 Sidney Lee, 'The Elizabethan Sonnet' in The Cambridge History of English Literature (CUP 1918) 248.

219 See Harold O White, Plagiarism and Imitation during the Early Renaissance (Harvard UP 1935) 202.

220 See Ezell (n 117) 21-40.

221 See Steven Berlin Johnson, 'The Glass Box and the Commonplace Book' (transcript of the Hearst New Media lecture, Columbia University, New York, 
plagiarism. In his Timber, Ben Johnson is heavily pillaging the ancients, with 25 excerpts from Quintilian, 21 from the younger Seneca, 11 from the elder Seneca, and several others from Horace, Plutarch, the younger Pliny, Aristotle and Plato. ${ }^{22}$ Voltaire found that Milton's Paradise Lost had reproduced more than 200 verses from the Sarcotis of the Jesuit Masenius, though he concluded that Milton 'imitated only what was worthy of being imitated'. ${ }^{223}$ The paternity of Paradise Lost was long under scrutiny. An extensive monograph of an Italian researcher, Zicari, purported to show that Milton's epic was sired by Adam Caduto, a tragedy written by the Calabrian monk Serafino della Salandra. ${ }^{224}$ Again, having Dryden and many others as a target, at the end of the seventeenth century, Gerard Langbaine published a comprehensive account of plagiarism in English drama, showing how widespread the practice was. ${ }^{225}$

As Paulina Kewes has argued - and as we will discuss later in Chapter 4 - following Langbaine's publication, the repeated accusations of plagiarism, which spared few authors, marked a changing cultural paradigm. ${ }^{226}$ A new creative paradigm based on autogenous originality and invention emerged from the ashes of imitative practices and erudite borrowing. In a few years the Statute of Anne would be enacted. Original authorship was on the rise and plagiarism was viewed more and more as a creative mischief. The imitative, cumulative and collaborative nature of creativity, however, still loomed large in the Romantic creative process. Well into the Romantic period, a range of British authors were repeatedly accused of plagiarism. In the early nineteenth century, appropriation strategies were most famously associated with Samuel Taylor Coleridge, 227 but Wordsworth, Shelley and Byron also collected their share of accusations. According to a study by Tilar Mazzeo, Plagiarism and Literary Property in the Romantic Period, early nineteenth-century British authors 'consistently privileged strategies of textual appropriation

22 April 2010) <https://stevenberlinjohnson.com/the-glass-box-and-the-common place-book-639b16c4f3bb>.

222 See Lindey (n 32) 78.

223 Voltaire, Philosophical Dictionary (H I Woolf trans, Alfred Knopf 1924) 217-218.

224 See Lindey (n 32) 77.

225 Gerard Langbaine, Momus Triumphans: or, The Plagiaries of the English

Stage; Expos'd in a Catalogue (1688).

226 See Kewes (n 215) 96-129.

227 See Thomas Mallon, Stolen Words: Forays into the Origins and Ravages of Plagiarism (Ticknor \& Fields 1989) 26-40 (discussing Coleridge's plagiarism). 
even as they emphasized the value of originality'. ${ }^{228}$ Mazzeo concludes that ' $[\mathrm{t}]$ he almost exclusive association of Romanticism with selforigination is largely a belated critical invention'. ${ }^{229}$ As Mazzeo noted, 'the cultural conventions of Georgian Britain privileged as literary achievements those novels, dramas, and especially poems that demonstrated mastery over a range of sources, and writers were given broad licence to borrow from the works of other authors so long as the appropriations satisfied particular aesthetic objectives and norms'.230 In sharp contrast with modern cultural conventions and legal provisions, these norms included borrowing from familiar and well-known sources, improvements and unconscious borrowing, among those creative practices that did not constitute plagiarism. In this context, trying to accommodate the tension between originality, appropriation and plagiarism, so powerfully lacerating in his authorial persona, Coleridge justified one notorious accusation of plagiarism from Schelling by claiming: 'I regard the Truth as a divine Ventriloquist: I care not from whose mouth the sounds are supposed to proceed, if only the words are audible and intelligible.' 231

A historical cross-cultural comparison of attitudes towards originality and borrowing may serve as a theoretical basis for supporting a critical argument against modern copyright law. The mimetic nature of human learning finds little recognition in copyright policies. Why have we rejected a paradigm under which creativity has strived for millennia? Quite indisputably, Aristotle was right in describing imitation as the defining character of humanity. Copying and reproducing is embedded in our biological nature, as 'copying makes us what we are ... [o]ur bodies take shape from the transcription of protein templates, our languages from the mimicry of privileged sounds, our crafts from the repetition of

228 Tilar Mazzeo, Plagiarism and Literary Property in the Romantic Period (U Pennsylvania Press, 2007) xi; but see Rebecca Moore Howard, Standing in the Shadow of Giants: Plagiarists, Authors, Collaborators (Albex Publ 1999) 67, 76 (noting that 'by the dawn of the Romantic era, it was no longer acceptable to stand on the shoulders of predecessors').

229 ibid xi.

230 ibid 5.

231 Samuel Taylor Coleridge, Biographia Literaria: Or, Biographical Sketches of My Literary Life and Opinions (Rest Fenner 1817) 153. 
prototypes'. ${ }^{232}$ Aristotle's observation has recently been regenerated by Marcus Boon in his excellent book In Praise of Copying. ${ }^{233}$ Put simply, Boon argues that copying is an essential part of being human and as such it is worthy of celebration. However, there is copious literature holding the same belief. In his magisterial lecture, An Unhurried View of Copyright, Benjamin Kaplan reflected:

if man has any 'natural' rights, not the least must be the right to imitate his fellows, and thus to reap where he has not sown. Education, after all, proceeds from a kind of mimicry, and 'progress', if it is not entirely an illusion, depends on generous indulgence of copying. ${ }^{234}$

Tackling more directly the paradox of originality in creativity, Pierre Laval has nicely reinforced the biological and intellectual metaphor by noting:

[n]ot since Athena sprung from the head of Zeus has an artist emerged fully formed. There is no such thing as a wholly original thought. Every idea takes a substantial part from what has gone before. Intellectual man, like biological man, displays the genes of his forebears. Titian's Venus and Goya's Maja are both present in Manet's Olympia. Cezanne's geometric reductions are found in Picasso's cubism. T. S. Elliot tells us that while lesser writers borrow, great writers steal. ${ }^{235}$

Laurence Peter once said that '[o]riginality is the fine art of remembering what you hear but forgetting where you heard it'. ${ }^{236}$ Yet that clever quip is itself unoriginal. ' $[\mathrm{b}]$ ooks serve to show a man that those original thoughts of his aren't very new after all', Abraham Lincoln is quoted as saying. ${ }^{237}$ Before him, Voltaire noted: '[o]riginality is nothing but judicious imitation. The most original writers borrowed one from another.

232 Hillel Schwartz, The Culture of the Copy: Striking Likenesses, Unreasonable Facsimiles (Zone Books 1998) 212. See also Stina Teilmann, 'Copy: From Wrong to Right' in Fiona Macmillan (ed), 6 New Directions in Copyright Law (Edward Elgar Publishing 2007) 68-69.

233 See Marcus Boon, In Praise of Copying (Harvard UP 2010).

234 Benjamin Kaplan, An Unhurried View of Copyright, Republished (And

With Contributions From Friends) (Matthew Bender Publ 2005) (1967) 2.

235 Pierre Leval, 'Fair Use or Foul? The Nineteenth Donald C Brace Memorial Lecture' (1989) 36 J Copyright Soc'y USA 167, 169.

236 Laurence Peter, Peter's Quotations: Ideas for Our Time (William Morrow 1977) 362 .

237 Alexander McClure, Abe Lincoln's Yarns and Stories: A Complete Collection of the Funny and Witty Anecdotes that Made Lincoln Famous as America's Greatest Story Teller (Forgotten Books 2007) (1901) 429. 
The instruction we find in books is like fire. We fetch it from our neighbor's, kindle it at home, communicate it to others, and it becomes the property of all. ${ }^{238}$ Waldo Emerson shared a similar view on the ephemeral nature of originality and noted that:

[t]he originals are not original. There is imitation, model and suggestion, to the very archangels, if we knew their history. The first book tyrannizes over the second. Read Tasso, and you think of Virgil; read Virgil, and you think of Homer; and Milton forces you to reflect how narrow are the limits of human invention. Paradise Lost has never existed but for its precursors ... . 239

References to authoritative quips over the originality's paradox may go on endlessly. They contribute to the understanding that, as I have tried to show so far, and as I will further investigate in the next chapter, the essential nature of human creativity is to be cumulative and collaborative. Authorship, therefore, lies in a collective notion, rather than an individual, because the collective and cumulative contribution to each creative act will ineludibly inform, shape and direct any individual additions. Again, one of the greatest exponents of Western authorship felt compelled to acknowledge this inescapable reality:

What am I then ... ? Everything that I have seen, heard, and observed I have collected and exploited. My works have been nourished by countless different individuals, by innocent and wise ones, people of intelligence and dunces. Childhood, maturity, and old age all have brought me their thoughts, ... their perspectives on life. I have often reaped what others have sowed. My work is the work of a collective being that bears the name of Goethe. ${ }^{240}$

From the Platonic mimessis to Shakespeare's 'borrowed feathers', the largest part of our culture has been produced under a paradigm where imitation, even plagiarism, social and collaborative authorship were constitutive elements of the creative moment. This notion seems to have been largely forgotten by modern policies regulating creativity and speech. As Boon agued, 'copying is pervasive in contemporary culture, yet at the same time subject to laws, restrictions, and attitudes that

238 Attributed to Francois Marie Voltaire in Tryon Edwards, Dictionary of Thoughts (1891) 392.

239 Ralph Waldo Emerson, 'Quotation and Originality' in IV Works of Ralph Waldo Emerson (Houghton, Osgood and Co 1876) 145.

240 Johann Wolfgang von Goethe, cited in Martha Woodmansee and Peter Jaszi, 'The Law of Text: Copyright in the Academy' (1995) 57 College English 769. 
suggest that it is wrong, and shouldn't be happening'. ${ }^{241}$ The 'formula that would acknowledge that all creativity relies on previous works' - as Vaidhyanathan writes - seems nowhere to be found in the spectrum of modern copyright policies. ${ }^{242}$ In fact, 'we have lost sight of such formula along the way'.243 The lost 'formula' makes harder to rebalance the traditional gift exchange between community and individual that creativity entails. $^{244}$ Individual creativity springs out of collective tradition. That collective tradition is the gift that all authors receive from the community. The individual contribution is the return gift that the community expects. Over-expansive and over-extended exclusive rights break the chain of gift reciprocation, or at least disrupt the fair balance of the exchange. It is in light of this unreciprocated gift that Joseph Proudhon noted that '[i]ntellectual property does not merely encroach on the public domain; it cheats the public of its share in the production of all ideas and all expressions'.245

The cumulative and collective nature of creativity stands in sharp contrast with the Romantic idea of absolute originality, original genius and lone authorship, which supported the relentless expansion of the copyright paradigm of exclusive rights. This apparently unresolvable conflict has opened a debate on the tension between the Romantic notion of authorship and the promotion of public interest. This debate radicalized with the emergence, in the digital environment, of the remix culture and new ethics of creativity based on collaboration, collective participation, and gift exchange. Romantic authorship has been put increasingly under scrutiny. The deconstruction of the conception of Romantic authorship now has a long history from the postmodernist thought of Barthes and Foucault ${ }^{246}$ to a recent legal scholarship, spearheaded by Jessica

\footnotetext{
241 Boon (n 233) 4.

242 Siva Vaidhyanathan, Copyrights and Copywrongs: The Rise of Intellectual Property and How It Threatens Creativity (New York UP 2001) 116. 243 ibid.

244 See eg Lewis Hyde, The Gift: Creativity and the Artist in the Modern World (Vintage Books 2007) (1979).

245 Joseph Proudhon, 'Les Majorats Littéraires: Examen d'un Projet de Loi Ayant pur but de Créer, au Profit des Auteurs, Inventeurs et Artistes, un Monopole Perpétuel (1862)' in Jan Baetens (ed), Le Combat du droit d'auteur (Les Impressions Nouvelles 2001) 140, 152-53.

246 See Roland Barthes, Image, Music, Text (Stephen Heath trans, Hill 1977); Michael Foucault, 'The Author Function' in Josué Harari (ed), Textual Strategies: Perspectives in Post-Structuralist Criticism (Cornell UP 1979). See also Mazzeo (n 228) 6 (noting ' $[\mathrm{t}]$ he postmodern position, [...] proposes that plagiarism is a charge used in a market economy to [...] perpetuate 'Romantic' ideas of solitary
} 
Litman, Martha Woodmansee, Peter Jaszi and James Boyle. ${ }^{247}$ My work seeks to contribute to that debate and the rebalance that it implies by deepening the exploration of the cumulative nature of creativity and connecting more tightly the past of creativity with its digital networked future. In the next chapter I will do so by observing closely the mechanics of production of premodern popular culture and epics as a quintessential example of the generative capacity of a cumulative, collaborative and communitarian open model of creativity.

genius by obscuring the extent to which all writing is necessarily collaborative and intertextual').

247 See eg James Boyle, Shamans, Software, and Spleens: Law and the Construction of the Information Society (Harvard UP 1996) 51-60; Martha Woodmansee and Peter Jaszi (eds), The Construction of Authorship: Textual Appropriation in Law and Literature (Duke UP 1994) 193; Peter Jazi, 'Towards a Theory of Copyright: The Metamorphoses of "Authorship" [1991] Duke L J 455; Jessica Litman, 'The Public Domain' (1990) 39 Emory L J 965, 966 (promoting the idea that no copyrighted work stands alone and viewing originality as 'translation and recombination'); The Bellagio Declaration, Statement of the Bellagio Conference, Cultural Agency/Cultural Authority: Politics and Poetics of Intellectual Property in the Post-Colonial Era, 11 March $1993<\mathrm{http}: / /$ case.edu/affil/sce/BellagioDec.html>. See also, more recently, Lior Zemer, The Idea of Authorship in Copyright (Ashgate Publishing 2007) (presenting a collectivistic model of intellectual property rights based on the argument that since copyright works enjoy profit from significant public contribution, they should not be privately owned, but considered to be a joint enterprise). 